Portland State University

PDXScholar

10-23-1991

\title{
The Effects of Captioned Videotapes on the Listening Comprehension Test Scores of ESL Students
}

Yuan-Chyuan Andy Lin

Portland State University

Follow this and additional works at: https://pdxscholar.library.pdx.edu/open_access_etds

Part of the Applied Linguistics Commons, and the Bilingual, Multilingual, and Multicultural Education Commons

Let us know how access to this document benefits you.

\section{Recommended Citation}

Lin, Yuan-Chyuan Andy, "The Effects of Captioned Videotapes on the Listening Comprehension Test Scores of ESL Students" (1991). Dissertations and Theses. Paper 4185.

https://doi.org/10.15760/etd.6069

This Thesis is brought to you for free and open access. It has been accepted for inclusion in Dissertations and Theses by an authorized administrator of PDXScholar. Please contact us if we can make this document more accessible: pdxscholar@pdx.edu. 
AN ABSTRACT OF THE THESIS OF Yuan-Chyuan Andy Lin for the Master of Arts in TESOL presented October 23, 1991.

Title: The Effects of Captioned Videotapes on the Listening Comprehension Test Scores of ESL Students.

APPROVED BY THE MEMBERS OF THE THESIS COMMITTEE:

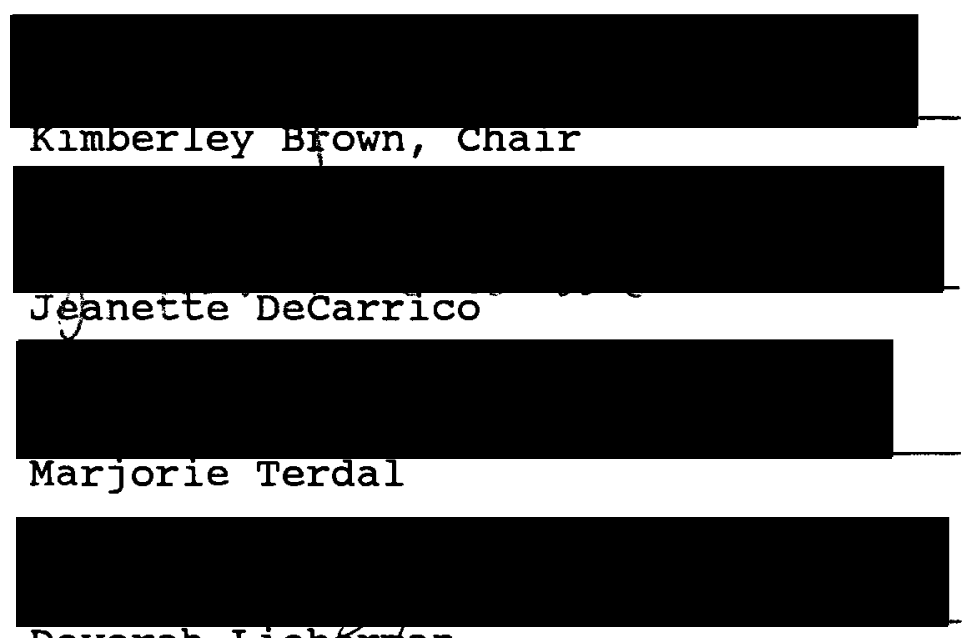

Devorah Lieberman

This study was meant to provide some empirical evidence to confirm or disconfirm the assumption that the use of captioned videotapes will enhance the listening comprehension of second language students. This study compared the listening comprehension test results of intermediate English as a second Language (ESL) students using videotapes with and without captions. Two episodes of an educational program were selected for the study. Students viewed one episode with captions and a second episode without captions. A total of sixty-four students participated in this study. Thirty-two 
students in class 1 watched Video I with captions first and then watched Video II without captions, and the remaining students in Class 2 watched Video I without captions and Video II with captions. Each class was exposed to both noncaptioned and captioned videos respectively.

The hypotheses postulated were:

1) ESL students watching a captioned videotape will score higher on a multiple-choice listening comprehension test, which measures vocabulary and implied information, than will the students watching a videotape of the same materials without captions.

2) ESL students watching a captioned videotape will acquire more vocabulary from the text of captions than will the students watching the videotape without captions.

3) ESL students watching a captioned videotape will better understand implied information (inference) at the word, syntactic, contextual, and thematic level from the text of captions than will the students watching the videotape without captions.

Two-Factor ANOVA procedures and $t$-distribution tests were used to compare the listening comprehension test results of the two groups. Two hypotheses were supported and one was rejected. Results shows that those students who received the captioned video treatment outperformed the students receiving the non-captioned video treatment in the inference category and in total scores, while in the vocabulary category there were no statistical differences between the group viewing captioned video and the group viewing non-captioned video. 
THE EFFECTS OF CAPTIONED VIDEOTAPES ON THE LISTENING COMPREHENSION TEST SCORES OF ESL STUDENTS

$$
\text { by }
$$

YUAN-CHYUAN ANDY LIN

A thesis submitted in partial fulfillment of the requirements for the degree of

\author{
MASTER OF ARTS \\ in \\ TESOL
}

Portland State University 1991 
TO THE OFFICE OF GRADUATE STUDIES:

The members of the committee approve the thesis of Yuan-Chyuan Andy Lin presented October 23, 1991.

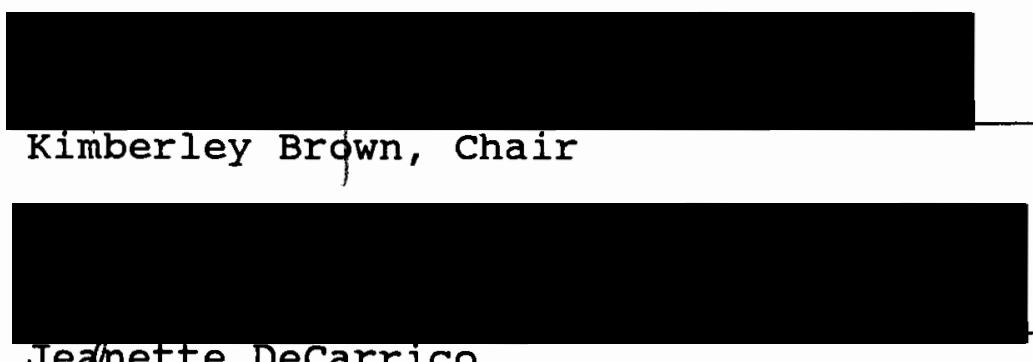

Jeghette Decarrico
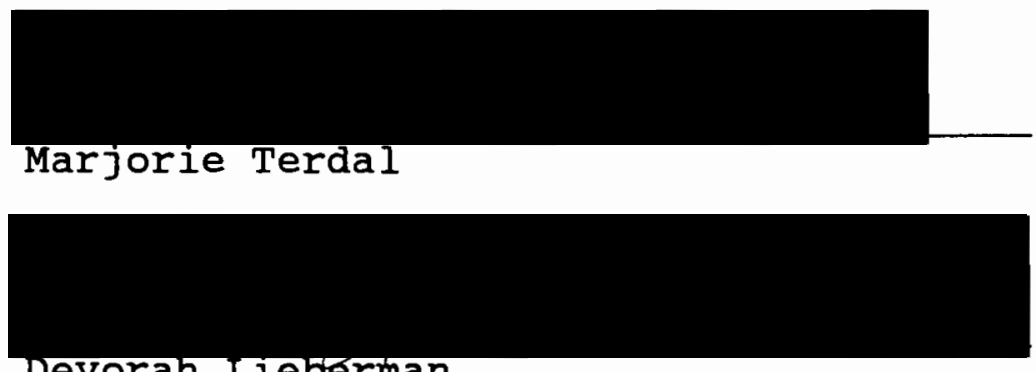

Devorah Lieberman

APRROVED:

James Nattinger, Chair, Department of Applied Linguistics

C. William Savery, Interim VicelProvost for Graduate studies and Research 


\title{
ACKNOWLEDGEMENT
}

I would like to thank the members of my committee:

\author{
Kimberley Brown \\ Jeanette DeCarrico \\ Marjorie Terdal \\ Devorah Lieberman
}

for their kind help and encouragement. In addition, I also want to thank my thesis advisor, Kim Brown, for her expert guidance. I also want to thank Michael Bess, John Harn, Laura Horani, and Susan Lindsay for their kind help during the experiment. Especially I would like to thank my brother, Yuan-Huei Robin Lin who sacrificed many working hours for helping me with the statistics. Finally, I would like to thank my parents, Fan-Ming Lin and Shou-shang Lee for their love, encouragement, and unending support. 
TABLE OF CONTENTS

PAGE

ACKNOWLEDGEMENT. ......................... . . . .

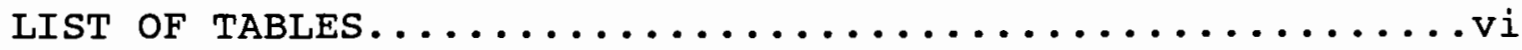

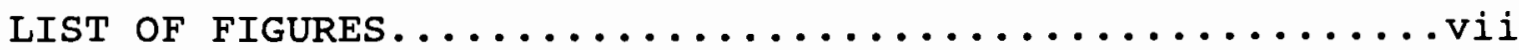

CHAPTER

I INTRODUCTION. .................... 1

Statement of Purpose................

Background..................... 2

Review of Related Literature..........4

Statement of Hypotheses.............6 6

Definition of Terms.............. 7

II REVIEW OF THE LITERATURE...............

Listening in $\mathrm{L} 1$ and $\mathrm{L} 2 \ldots \ldots \ldots \ldots \ldots \ldots \ldots$

Listening Problems Which Nonnative

Speakers Encounter................16

Media and Listening Comprehension.......17

Use of Audio-Visual Media

Use of Captioned Media

Comparative Studies of Video and

Captioned Video in Listening

Comprehension

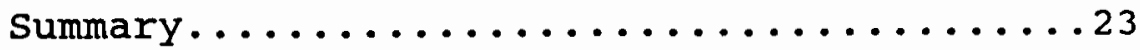

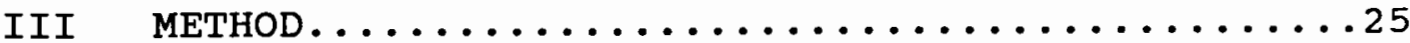

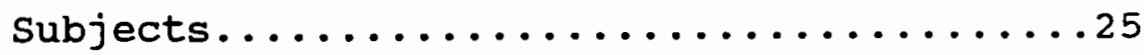

Instruments and Materials...........26 


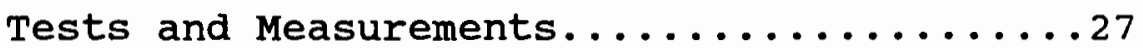

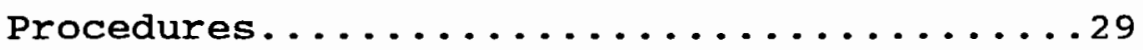

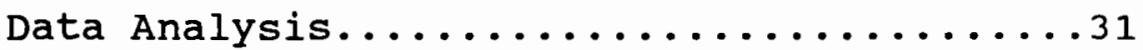

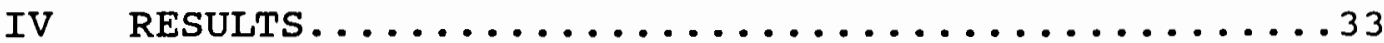

Results of the Listening Comprehension

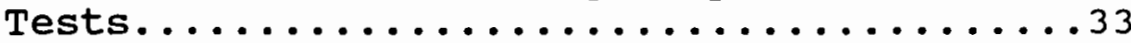

V INTERPRETATION OF TEST RESULTS ............46

Interpretation of the Comparison of

Group Test Results.................46

Interpretation of the Vocabulary Results...47

Interpretation of the Inference Results...49

VI CONCLUSIONS AND RECOMMENDATIONS ............51

Conclusions from study..................52

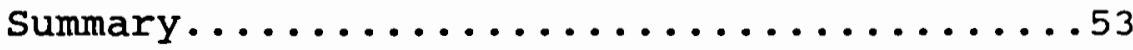

REFERENCES................................. 57

APPENDICES

A TRANSCRIPTS OF THE TWO VIDEOTAPES...........62

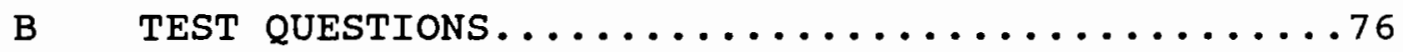

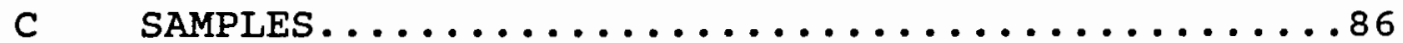




\section{LIST OF TABLES}

TABLE

PAGE

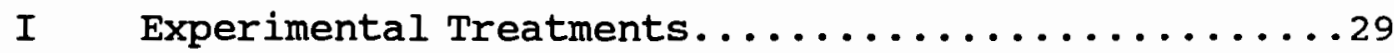

II Test Results for class $1 \ldots \ldots \ldots \ldots \ldots \ldots \ldots$

III Test Results for class $2 \ldots \ldots \ldots \ldots \ldots \ldots \ldots$

IV Two-Factor Analysis of Variance............37

V Race to Save the Planet: Total Scores..........38

VI Global Warming: Total Scores................... 39

VII Race to Save the Planet: Inference...........40

VIII Race to Save the Planet: Vocabulary...........40

IX Global Warming: Inference...............41

X Global Warming: Vocabulary..............41 


\section{LIST OF FIGURES}

1. Total Score Comparisons for Videos:

with Captions vs. without Captions...........43

2. Vocabulary Score Comparisons for Videos:

with Captions vs. without Captions...........44

3. Inference Score Comparisons for Videos:

with Captions vs. without Captions.........45 


\section{CHAPTER I}

\section{INTRODUCTION}

Recently, with the development and extensive availability of audio-visual technology, a great variety of materials and resources have been employed in second language classes. video materials are among frequently used resources to enhance the listening comprehension skills of second language learners. Video is viewed as an essential way to bring authentic speech as well as visual images into the second language classroom. While many studies have been done on techniques and applications of video to the second language classroom, and some research has been conducted to show the pros and cons of using video materials on the listening comprehension of second language learners, there is ample room for further studies evaluating the effects of using video materials in the second language classroom.

\section{STATEMENT OF PURPOSE}

This study is meant to provide some empirical evidence to confirm or disconfirm the assumption that the use of captioned television videotapes will enhance the listening comprehension of second language students. This study compares the listening comprehension test results of intermediate and 
advanced English as a Second Language (ESL) students using videotapes with and without captions. Students enrolled in higher level listening classes in ESL programs in several local colleges and universities were asked to watch two videotapes, one with captions and one without captions. After viewing the videotapes, they were given multiple-choice questions related to the text of the captions. The data were collected and analyzed, and the results were tabulated to find out if there were any notable differences between the test scores of the group viewing the captioned program and the group viewing the non-captioned program.

\section{BACKGROUND}

In the course of my graduate study, I have had many opportunities to make contact with ESL students in our ESL programs. A consistently mentioned concern has been how to strive to be successful in their academic performance. Because of the role listening plays in this process, it is critical for ESL instructors and students to become familiar with what kinds of aids will enhance students' listening comprehension. Many ESL students or non-native speakers tend to experience listening comprehension problems in second language (L2) settings, problems such as following the speed of others' speech, comprehending key vocabulary of a lecture, and understanding slang or jokes. These are the major 
hindrances to the listening comprehension of ESL students (Celona, 1983; Powers, 1985).

In order to improve their listening comprehension abilities, many ESL students are advised to obtain a television, and to watch and listen to popular programs on television written by professional playwrights and performed by professional actors conversing in a variety of Englishes. However, with limited vocabulary and lexical knowledge, many ESL students at the beginning or intermediate level are sometimes unable to follow the aural information of TV programs. Two of my Chinese friends who are in the ESL program have bought telecaption decoders which can be attached to their TV sets as supplementary aids. The telecaption decoder (or closed-captioning decoder) can supply captions or subtitles at the same time that the viewer is watching television. They both think it is a marvelous device because the showing of additional captions on $T V$ enables them to follow the aural message as well as the captions word by word. They believe they can follow the message more easily and learn more vocabulary through the captions. If there are any vocabulary items, idioms, or phrases in the $\mathrm{TV}$ programs that confuse them, they are able to write them down and look them up in the dictionary.

The idea of using telecaption decoders as a means to improve the listening comprehension of ESL students is interesting because recently there have been a lot of 
advertisements advocating the use of captioned TV and videotapes to improve ESL students' ability to learn English. Some language educators claim that captioned TV can be used as an educational tool, suggesting that captions reinforce listening comprehension and assist in developing reading and speaking fluency in students learning English as a second language (Hoffman, 1986; Wilson, 1986; Goldman, 1988). However, there has not been enough empirical research concerning the use of captioned materials as an aid to enhance ESL students' listening comprehension. The goal of this research is to employ captioned television videotape programs in ESL listening classes, and to measure and analyze the effects of captioned videotapes on the listening comprehension test scores of ESL students.

\section{REVIEW OF RELATED LITERATURE}

Statistics show that the average eighteen year old in the U.S. has watched about 18,000 hours of television. Such an exposure might influence the viewer's verbal language, thought process, and behavior (Liberman, 1983). Some researchers condemn television as a relatively worthless medium (Seal, Mead, \& Ward, 1985). Despite the negative criticism of many programs, television remains a powerful medium for the carrying of information. Based on a survey of ESL students' academic problems, Celona (1983) reported that ESL students believed that in order to learn English better they needed to 
converse with native speakers and to make use of other helpful aids such as television and dictionaries. Cullen (1990) in a conference paper "Making Videotape Lessons Productive," demonstrated video lessons such as TV news program excerpts, sitcoms, and MTV to teach ESL students both language and culture. Both Celona and cullen strongly recommend the application of TV programs in the ESL classroom.

Recently, some language educators have advocated the use of captioned television programs as an aid to improve the listening comprehension of ESL students. Berwald (1979) suggests that the use of captions is of great value not only to hard-of-hearing viewers, but also to those whose native language is not English. Hoffman (1986) also strongly recommends using captioned videotapes to teach ESL listening and speaking classes. They both argue that the combination of aural messages, visual images, and captions facilitate the listening comprehension of ESL students.

Based upon the above recommendations, captioned videotapes might have considerable value for improving ESL students' listening comprehension ability. Although some comparative studies have been conducted concerning the effects of audiotapes and videotapes on listening comprehension (Ortmeyer, 1980; Parry \& Meredith, 1984; Tyson, 1989), little research has been done concerning the use of videotapes with captions and without captions. Only two empirical studies conducted by Markham (1989) and Pirolo (1991) supported the 
assumption that listening comprehension of ESL students will improve a certain degree from viewing television videotapes with captions. Since it is believed and supported by some language educators that the use of captioned videotapes might be employed in the L2 settings, further research concerning the use of captioned video materials as an aid to improve the listening comprehension of ESL students or non-native speakers needs to be conducted.

\section{STATEMENT OF HYPOTHESES}

This study examines and compares the listening comprehension test results of ESL students using videotapes with and without captions. The hypotheses posed are as follows:

1) ESL students watching a captioned videotape will score higher on a multiple-choice listening comprehension test, which measures vocabulary and implied information, than will the students watching a videotape of the same materials without captions.

2) ESL students watching a captioned videotape will acquire more vocabulary from the text of captions than will the students watching the videotape without captions.

3) ESL students watching a captioned videotape will better understand implied information (inference) at the word, syntactic, contextual, and thematic level from the text of 
captions than will the students watching the videotape without captions (see further explanation under Definition of Terms, p.8) .

\section{DEFINITION OF TERMS}

Closed Captioning: Originally, television captioning was of the "open" variety. In open captioning, the captions are superimposed on the picture and are visible to all viewers, hearing and hearing-impaired alike. Unfortunately, not all hearing viewers were sympathetic to the addition of captions to popular programs. This spawned a new idea: the captions could be broadcast invisibly and would become visible by using special equipment, only for those viewers who wanted them. This led to the development of the closed captioning system (Decker, 1980).

Telecaption Decoder: It also has another name, closed captioning decoder. This device was invented to be attached to the television which could decode the "closed captioned" programs and make the captions visible to the viewers.

Three Aspects of Language: The developer of multi-level captioning suggested that hard-of-hearing viewer uncertainty will be reduced in three aspects of language which were analyzed and used in the captioning system (Shulman, 1979): vocabulary, syntax (grammatical 
structure), and inference (degree of implied information). This can also be applied to L2 settings. Since ESL viewers see and hear new vocabulary words, and new grammatical structures, they are better able to process them than if they simply hear them. When they are seeing additional captions, they are better able to combine direct and indirect information to draw conclusions.

Inference Aspect: Words and syntactic structures provide only a framework of meaning. In order to interpret accurately what the writer intended, the reader has to organize and expand these explicit meanings. During this process, meanings must be frequently filled in from information which is not directly stated. These implied meanings are called inferences. Four categories of inference are introduced in the Captioning Reference Manual (1979): word, syntactic, contextual, and thematic. According to the Multilevel Guidelines for Linguistically Controlled Reading Materials described by Decker (1980: 59-62), word inference accounts for one's ability to interpret individual words with multiple meanings. It is based on sentence relations and broader context. Syntactic inference refers to meanings which are elaborations of what we understand from our syntactic analysis of a sentence. Contextual inference involves the addition of meanings which complete a scene or description. Thematic 
inference, sometimes referred to as story grammar, results from recognizing the broad structure of discourse in stories or conversations. An example of the use of inference is demonstrated as follows:

Today was Janet's birthday. John and Andy went to the store. They had to get presents. "I will get her a Barbie doll," said John. "Don't do that," said Andy." Janet has a doll. She will make you take it back."

(adapted from Charniak, 1976)

From the above example we can see inference at all four levels. Word inference would cause the reader to interpret "store" as a place where one buys gifts (rather than groceries), and "get" as the act of purchasing (rather than the act of becoming). Syntactic inference would interpret "Don't do that" to mean not to buy a doll and would provide appropriate referents for each of the pronouns (they, I, he, you, and it). Contextual inference would provide additional information such as: (1) John and Andy wanted to get presents for a particular person, Janet, on a particular day, her birthday; Andy advised John not to buy a doll because he believed that Janet already had at least one doll and that Janet would not want two. Thematic inference would lead the reader to picture the setting in a store on the day of Janet's birthday. The first episode begins with an 
initiating event -- a trip to the store -- and with the statement of a goal; i.e., the boys must bring appropriate presents for Janet. This episode leaves the reader awaiting further attempts of the two boys to achieve the goal and decide what to buy Janet. 


\section{CHAPTER II}

\section{REVIEW OF THE LITERATURE}

Listening is the most frequently employed skill in daily language use. Research results show that time spent in communicating divides into approximately 50\% listening, 25\% speaking, $15 \%$ reading, and 10\% writing (Morley, 1984). Listening comprehension in language is crucial in that language development, reading, and spelling skill are largely dependent upon one's auditory perception abilities. In the 1960's, the dominant audiolingual method emphasized intense concentration on spoken languages as the primary teaching objective and viewed listening as a passive skill. Beginning in the 1970's and continuing into the 1980's, there has been a steady increase in attention to the role of listening in language learning theory and pedagogy. The focus on auditory input -- its quality, its quantity, and how it is actively processed -- has been recognized in both second language acquisition research and in second language instructional programming (Friedman, 1978; Goss, 1982; Wolf, 1983; Morley, 1984; Richards, 1987; Brown \& Palmer, 1988). Just as the role of listening comprehension has changed from that of a passive skill in the audiolingual period to active language processing in the interactive period, the means of testing listening 
comprehension has also changed from recall of distinct segments to recall of more general information. Using media to enhance listening comprehension has become more diversified and prominent. Audiotapes have been sometimes supplemented and replaced by videotapes, or recently even by captioned videotapes. Some research has been done on the use of audio and video tapes in listening comprehension (Els, 1984; Svensson \& Bogarskola, 1985; Peck, 1986; Biggs, 1990), but the results have often been contradictory. Little research has been conducted on the use of captioned videotapes as a means to improve listening comprehension. For the second language learner, listening is a complicated, challenging task; for the language educator, teaching listening is a problem-solving task centered on answering and solving listening problems the students encounter and employing appropriate methods and authentic materials in the teaching of listening comprehension.

\section{LISTENING IN L1 AND L2}

Listening is a different process of thinking, a process by which what is heard is weighed, analyzed, sorted, related, classified, evaluated, and judged (Anilla, 1963, p.13). Native speakers usually listen to their own language without much effort. Very often the degree of effort depends upon the listening task. Watching and listening to a soap opera on television requires less effort than listening to an academic 
lecture, especially if notetaking on the lecture is necessary and later recall of the lecture is required on a test. Many different components are involved in the listening process. Schank and Abelson (1977) describe the crucial role of prior knowledge (script and schema theory) in comprehension. Goss (1982) identifies a framework dividing auditory perception and message comprehension (listening) into three parts: signal processing (segments and structures), literal processing (meaning and simple implications), and reflective processing (critical analysis and appreciation).

One component, the basic units of meaning involved in comprehension, consists of using knowledge of the syntax of the target language and real world knowledge. With such knowledge, the listener is able to chunk the incoming message into segments or constituents and then identify the meaning (Richards, 1987). Therefore, a sentence like "I am happy that John's wife has found their lost child," will be divided into "I am happy/that John's wife/has found their lost child." If the listener chunks the sentence as follows, "I am/happy that John's/wife has/found their lost child," it will be difficult for the listener to derive the meaning. The listener also needs a knowledge of vocabulary and a knowledge of the phonetic, syntactic, semantic, and pragmatic characteristics of each segment respectively and the message as a whole. Native speakers can make use of their understanding of the nature and goals of conversation and reduce the amount of 
effort needed to predict the incoming message. Such a listening strategy is what Goss (1982) termed a "predict-thenconfirm" strategy.

Script or schema knowledge plays an important role on information processing. Richards (1983) describes a script as what the listeners know about particular situations, and the goals, participants, and procedures which are commonly associated with them. The listener's knowledge of a classroom script, library script, hospital script, and so on, enables him or her to interpret a great deal of the language of everyday life. If the listener lacks a relevant script, comprehension may be difficult. Since some schema knowledge may be culturally specific, non-native speakers may lack such scripts and have additional problems for listening comprehension.

other factors that might affect listening comprehension involve the listener's attitude, attention, and motivation (Friedman, 1978; Richards, 1978; Anderson, 1988). The listener's ability to understand a variety of speech registers and the nonverbal cues may also affect one's comprehension of the message.

A variety of approaches to listening comprehension have been applied in the L2 classroom. A great deal of research is based upon Krashen's (1985) input hypothesis. Krashen has proposed a general theory of language acquisition that applies both to natural settings and to classrooms. He suggests that 
language learners acquire by understanding input containing structures that are a bit beyond their current competence (p.38). Thus the learners move from their current level "i" to the next level " $i+1$ ". Such input, which is one level above that which the learner is able to produce, is the optimal environment for language learning. Krashen also offers two hypotheses, paraphrased: (1) learners acquire language by listening -- not by speaking; and (2) they keep their attention on the meaning -- not on the language itself. Brown and Palmer (1988) have further developed a listening approach based upon Krashen's input hypothesis and acquisition-learning hypothesis. They introduce a model of conscious learning and subconscious acquisition. In this model, attention to meaning and attention to language are applied separately to (listening/reading) understanding and speaking. The model consists of four interrelated parts: (1) listening with attention to meaning (comprehensible input); (2) speaking with attention to meaning (zero input); listening with attention to language (segments, structures, dialogues, memorization, and listening practice); and speaking with attention to language (same as the third level plus oral practice instead of listening practice). Krashen's theory would fit into the first part. other approaches to language learning or acquisition can also fit into this chart. It seems that this is a good model that language teachers can 
draw upon to develop techniques and materials for the teaching of listening comprehension.

LISTENING PROBLEMS WHICH NONNATIVE SPEAKERS ENCOUNTER

Non-native speakers, more or less, tend to experience problems concerning listening comprehension in L2 settings. Celona (1983) in her survey of 25 international students gathered information on four specific aspects of their American college experience (recruitment, orientation, adaptation, and acculturation) and their experience with learning English. The most common problems found were in aural comprehension, slang and colloquialism, speed of other's speech, producing speech, and understanding jokes. In Power's (1985) report, undergraduate and graduate English faculty were surveyed about students' academic listening needs. The faculty members identified nine specific problems related to listening skills that non-native speakers experienced with difficulty. The problems identified are: (1) following lectures given with different speed; (2) comprehending key vocabulary related to the topic of a lecture; (3) deducing the meaning of words from the context in which they appear; understanding informally structured lectures; (5) identifying the role of discourse cues; (6) following different modes of spoken lectures; (7) following different modes of audio lectures; (8) recognizing irrelevant matters; (9) recognizing 
the function of such features as change of pitch and sentence stress.

Knowing the listening problems that non-native speakers may encounter and assessing the degree to which non-native speakers experience difficulties with the current listening skills and activities, second language instructors are more able to employ adequate approaches, curricular design, and procedure in the teaching of listening comprehension. Authentic listening activities using various aids and media have been suggested to replace conventional listening activities. It is believed that the closer the learner comes to a language, the greater is his or her enthusiasm, and the greater the learner's own desire and enthusiasm is, the greater his or her success will be (Porter \& Roberts, 1987).

\section{MEDIA AND LISTENING COMPREHENSION}

With the development and extensive availability of audiotechnology during the 1950's and 1960's, the use of audiotapes was at its peak. Students often spent hours in a language lab listening to audiotapes and practicing drills with repetitions, substitutions, and fill-ins. With improved facilities and modern technological equipment, interest in the use of audiotapes gradually gave way to the use of videotapes. Video is viewed as an essential way to bring authentic speech from a great variety of speakers into the classroom. other audiovisual aids which might enrich the student's language 
learning experience are often incorporated into the language teaching programs. A few second language instructors have attempted to employ captioned television programs or films in their language teaching (Hoffman, 1986; Markham, 1989). The following sections will focus on the applications of audiovisual media, captioned media, and relevant research.

\section{Use of Audio-Visual Media}

Visual elements used in the audiovisual method could be objects and situations which are introduced into the classroom by means of slides, pictures, films, etc. (Els, 1984). Peck (1986) draws on his own experience in teaching English as a second language to describe how audiovisual aids such as overhead projectors, video tape recorders, television, movies, and slides can help ESL adult learners. Cullen (1990) in a conference paper "Making Videotape Lessons Productive," demonstrated video lessons such as TV newsprogram excerpts, sitcoms, and MTV to teach ESL students both language and culture. Biggs (1990) uses movies to teach listening comprehension. He employs the Focal skill (coined by Hastings, 1988) in listening comprehension according to the following procedure. First, the instructor chooses films with "action" and popular movies which appeal to the viewers. Then the instructor previews the selected film and integrates the target vocabulary and sentences into pre- or post-listening exercises. When teaching the lesson, the instructor focuses on meaningful input and questioning techniques. students are 
encouraged to play an active role in class. By reassembling chunks of audio-visual information into their own, practicing exercises, and interacting with teacher and peer group, the students might be able to improve their listening comprehension ability. However, empirical research is needed to ascertain the effectiveness of such approaches.

Many language educators advocate the use of video as a means to increase listening comprehension. Svensson and Bogarskola (1985) mentioned that video can show gestures, facial expressions, and other nonverbal behaviors as well as verbal messages simultaneously. Television programs provide authentic listening tasks. Since videotape can be rewound and replayed, one recommended approach is to play a short scene or excerpt several times; between each showing the instructor can give meaningful input and request feedback from learners. other techniques mentioned are: turning off the sound and allowing visual image and information only; pausing the tape to focus on the picture or to ask students what is going on and what is coming next; allowing students to make their own running commentary; and asking students to explain, compare, relate, and comment.

some researchers, though recognizing the benefits of video, warn of potential problems in the use of video materials (lonergan, 1984; Macwilliam, 1986; Searls, Mead, \& Ward, 1985). They claim that unforced viewing, i.e., watching videos for entertainment, does not enhance one's language 
proficiency. At home, people usually watch $T V$ for entertainment. Unlike language instructors, TV makes no demands. The language teachers have to act as facilitators, as bridges between the machine and the viewers, and make sure that the viewers develop positive relations with the video.

\section{Use of Captioned Media}

Captioned media, usually referred to as captioned television, has been available since the 1970's (Boyd \& Vader, 1972). Similar to subtitles on foreign films, captioned media was originally used in the education of hearing impaired students. Originally, television captioning was of the "open" variety that was shown to all viewers. However, many viewers complained that the captions were distracting, especially when they rephrased the original audio track into simplified or shortened form (Decker, 1984, p.11). This criticism led to the development of the closed captioning system. In such a system, captions could be broadcast invisibly. closed captions can be seen only if one has a specially equipped television or a special decoding device (telecaption decoder).

Captioned television has received wide attention as a tool for teaching reading to hearing impaired students (Blatt \& Sulzer, 1981; Decker \& Montandon, 1984; Koskinen, 1986). Some studies show that captioned television has proven to be effective for improving the reading comprehension of hearing children (Goldman \& Goodman, 1988; Wilson \& koskien, 1986). Unfortunately, very little research has been conducted 
concerning the use of closed-captioned television as an aid to improve the listening comprehension of hearing second language students. Berwald (1979) claims that captions are an excellent way to teach English as a second language or foreign language. She emphasizes that "the spoken commentary, the visual images, and the captions combine to provide clarification as well as immediate practice with the receptive skills of listening and reading" (p.375). Similarly, Hoffman (1986) strongly recommends using captioned videotapes to teach ESL listening and speaking. He argues that auditory messages are more easily followed by foreign speakers when they have the information supplied by the speakers' body language. When more enforcement in the form of captions is provided, the listeners can follow much more easily. Based upon these recommendations, captioned videotapes might have considerable value for improving second language students' listening comprehension ability. However, the existing empirical research supporting this is very limited.

Comparative studies of Video and Captioned Video in Listening Comprehension

Numerous research projects have been conducted in both $\mathrm{LI}$ and $L 2$ to compare the effects of the medium on the listening comprehension of students. Most comparative studies have made use of audiotapes versus videotapes. Some researchers found no significant difference between the audio and video materials (Wright, 1971; Durio \& Kildow, 1979). Some studies 
supported the hypothesis that students who watched a videotape would score higher on a listening comprehension exam than would those who listened only to the audio (Jackson, 1979; Parry \& Meredith, 1984; Tyson, 1988), while one study conducted by ortmeyer and Goldstein (1980) supported that the audio alone would be more effective than the video. There have been no consistent results in the studies that have been conducted.

Recently, there have been a lot of advertisements advocating the use of captioned $\mathrm{TV}$ and videotapes to improve ESL students' ability to learn English. Some language educators claim that captioned TV can be used as an educational tool and that captions reinforce listening comprehension and assist in developing reading and speaking fluency in students learning English as a second language (Hoffman, 1986; Wilson, 1986; Goldman, 1988). However, there has not been enough empirical research concerning the use of captioned videotapes as a means to improve listening comprehension of "hearing" second language students. Markham (1989), conducted a study to determine the effects of captioned television videotapes on the listening comprehension of university students studying English as a second language. The subjects were 76 ESL students at three different levels (beginning, intermediate, and advanced). At each level groups of students were assigned to view one videotape concerning termites with or without captions and a second videotape 
concerning solar buildings with or without captions. After viewing the two videotapes, the students were given two multiple-choice reading comprehension tasks. The questions were constructed by combining the vocabulary and the syntactic pattern contained in the text of captions. Results showed that the beginning, intermediate, and advanced ESL students who viewed the videotapes with captions demonstrated better comprehension than did those without captions. Another study, conducted by Pirolo (1991) with similar procedures and method, also revealed that students who saw the captions received consistently higher scores than those who did not.

The results of both studies are consistent with the previously discussed supposition regarding the effects of captions on hearing impaired and hearing $\mathrm{L} 1$ students. According to the studies, ESL students benefit from viewing videotape television materials with captions. Yet more empirical research is needed to explore the utility of employing captioned video materials for enhancing the comprehension of second language students.

\section{SUMMARY}

With the steadily increasing availability of ESL teaching resources, expanded use of video and captioned video materials in the ESL classroom seems assured. However, there seem to be few studies available to support the superiority of captioned video in teaching listening comprehension in ESL. Only two 
empirical studies to date support the assumption that listening comprehension of ESL students improves a certain degree from viewing captioned television videotapes. Since it is believed and supported by some language educators that the use of captioned video resources which combine the spoken messages, the visual images, and the captions together do help the hard-of-hearing students and might be applied to the ESL field, further research concerning the use of captioned video materials as an aid to improve the listening comprehension of ESL students or non-native speakers needs to be explored. 


\section{CHAPTER III}

METHOD

The video materials chosen for the listening comprehension test were two episodes of an afternoon television program from the Oregon Public Broadcasting (OPB) channel. Since the ESL students participating in the study had to attend Listening and Speaking classes in the afternoon, an afternoon program was chosen to minimize the possibility that the ESL participants might have already seen the program. Four videotapes, two with captions and two without captions, were recorded in advance. Two groups of students (Class 1 and Class 2) participating in the experiment were assigned first to watch one video episode with captions and then a second video episode without captions. Comprehension of the videotapes with or without captions was measured by multiplechoice tests. After viewing each videotape, students were asked to take a test within a thirty-minute period.

\section{SUBJECTS}

This study was conducted at three colleges. The subjects were sixty-four intermediate and advanced students enrolled in ESL classes at Portland State University, Pacific University, and Western Business college. Thirty-two students were in 
Class 1 and thirty-two in Class 2. Most of the participating students were from Asian countries (China, Korea, Japan, and Taiwan), except a few were from the Middle East and Latin America.

All students who participated in the experiment had been placed in either the intermediate or advanced level by their respective colleges or universities. Each institute had different criteria for determining placement. Normally the placement was based on the test results from either the Michigan Test of English Language Proficiency (MTELP) or the Test of English as a Foreign Language (TOEFL). TOEFL scores were available from all three institutes, while MTELP from one school only.

The TOEFL scores of the participating students ranged from 450 to 525 and the MTELP scores from 65 to 85 . Students from each institute were evenly and randomly assigned to either Class 1 or class 2 in order to balance the proficiency level in the experimental treatments.

Each group (Class 1 or Class 2) in the experiment was exposed to both non-captioned and captioned videos respectively in order to achieve balanced exposure to the treatment variable (with or without captions).

\section{INSTRUMENTS AND MATERIALS}

Two episodes of an educational television program from the OPB channel were selected for this study. The title of 
the program is "Race to Save the Planet," a look at environmental issues around the world. The first episode (12 minutes) concerns closing a toxic waste dump in California, and the second episode (10 minutes) addresses the problem of global warming. The rationale for selecting this program was based on Cullen's (1990) paper "Making Videotape Lessons Productive" and the recommendation of an ESL teacher. They both had found such kinds of TV programs suitable for listening comprehension classes at the intermediate or advanced level. Other factors considered were students' prior knowledge and interest. Since environmental problems had long been the issues discussed among newspaper and magazines, the selection of such a program might serve an educational purpose.

\section{TESTS AND MEASUREMENTS}

The students were given two multiple-choice comprehension tests based on the two episodes and created by the researcher. The questions tested were constructed by combining two major aspects of language in the text of the captioned material -vocabulary and inference -- which are analyzed and used in the multi-level captioning system for controlling the complexity of language at three levels. The captioning Reference Manual (Shulman, 1979) draws upon three aspects of language, vocabulary, syntax, and inference, and creates three levels for captioning. According to the manual, the vocabulary for 
each level is determined by a standardized list based on hearing children's vocabulary comprehension (Taylor, Frackenpohl, \& White, 1969). Analysis of Syntax is based on the theory of transformational generative grammar (chomsky, 1965). Inferred information (inference) is that which is not explicitly stated in a message but rather is implied (Decker, 1980). Level 1 vocabulary contains words with a single meaning. Level 1 sentences are short and simple, following subject-verb-object word order. Level 2 includes idioms and words with multiple meanings, and syntax at this level may contain compound structures, some types of complements, and more adverbs and prepositional phrases. Vocabulary at level 2 includes words found in third-grade text. Level 3 materials are the most difficult to read and the viewers need to understand some types of complex sentences which include relative clauses, if/then sentences, negative questions, and infinitive complements. Level 3 captions contain fourth-grade words (based on a standardized vocabulary list) and a greater number of idiomatic expressions than the two simpler levels. The questions on the test materials were divided into two parts: vocabulary and inference, which were based upon the two major aspects of language (vocabulary and inference) used in the captioning system. The first part contained fifteen multiple-choice questions and the second part contained fifteen questions also. There were thirty questions in each test. Webster's New World Dictionary (1984) and Webster's New 
World Thesaurus (1983) were used as references during the making of the Vocabulary questions. Inference questions drew upon the four categories of inference introduced in the Captioning Reference Manual (1979). After viewing each videotape the students were tested and the results of their test scores provided the evidence to support or reject the working hypotheses.

\section{PROCEDURES}

ESL students enrolled in ESL summer programs at three colleges were asked to view two video episodes of an educational program, "Race to save the Planet." students watched one video episode concerning toxic waste dumps with or without captions and a second video episode concerning global warming with or without captions. Students assigned to class 1 watched Video I with captions first and then watched Video II without captions. Students assigned to class 2 watched Video I without captions and Video II with captions. Each class was exposed to both captioned and non-captioned videos respectively. A visual chart of the experimental treatments is given in Table $I$.

TABLE I

EXPERIMENTAL TREATMENTS

Video I Video II

Class 1

with captions

without captions

Class 2

without captions

with captions 
The students were first given a consent form explaining the purpose of the research and an introduction describing the tapes to be shown. After viewing each videotape, the students were given a multiple-choice test within a thirty-minute period.

Prior to the main data collection stage, the test questions were pilot-tested with a small set of beginning and intermediate students (three to five students per level) at Concordia college and Western Business College. These students did not participate in the experiment. The purpose for the pilot-testing, which was based upon "Test Development for Assessing Achievement in Listening and Speaking" (Plattor, et al., 1978: p.23), was to (1) determine if the subjects could understand the directions; (2) determine if the administrative procedures were adequate; (3) determine if the options in multiple-choice items were working properly; (4) determine the amount of time required for group of items; (5) determine if the items discriminated or were too difficult or too easy (floor and ceiling effects); (6) determine the practicability and reliability of the scoring system.

since the form of the test questions created was exactly like that of the TOEFL test with which most ESL students were familiar, the students who were pilot tested did not have any difficulties following directions and executing correct procedures. The time needed for each test was approximately thirty minutes as planned. Only a few of the test questions 
were modified or eliminated because of the floor and ceiling effects; i.e., either too easy or too difficult (Plattor, et al., 1978) .

A timetable of the whole procedure of the experiment follows:

Week One: Record four tapes from the same TV program, two with captions and two without. Then transcribe the captions of the two episodes and design two tests; each test is based upon the transcription of each episode respectively.

Week Five: Pilot-test the test questions with a subset of ESL students.

Week Eight: Administer the video lessons to the two groups followed immediately by multiplechoice tests.

Week Ten: Analyze the data collected and draw conclusions.

\section{DATA ANALYSIS}

The independent variable is the videotapes used for the listening comprehension, either with captions or without captions. The dependent variable is the student scores on the multiple-choice test. The scores of the students in this experiment were calculated in two categories on the multiplechoice test questions: vocabulary and inference. Each 
category contained fifteen questions. Altogether there were thirty questions on both tests.

Immediately after tabulating the vocabulary and inference categories on each test, the scores of the groups viewing captioned video and non-captioned video were compared using 2 $\mathrm{x} 2$ ANOVA procedures. The TwO-Factor ANOVA was first used to indicate that there was no effect on the tests due to different video contents, and later to explore whether there were statistical differences due to videos with or without captions. T-distribution tests were then used to compare the total scores of the students viewing captioned video and noncaptioned video as a whole, and also to compare each category (vocabulary and inference) respectively in order to support the working hypotheses. 
CHAPTER IV

RESULTS

The test results of the experiment are discussed in this chapter. All students who participated in this study were divided into two groups: Class 1 and class 2 . Originally there were sixty-four subjects in the experiment; however, four subjects were discarded because one student fell asleep while watching the videotapes, one left during the intermission, and two students did not wish to answer the test questions. The measures used for calculating the test results include two $2 \times 2$ ANOVA procedures and t-distribution tests.

RESULTS OF THE LISTENING COMPREHENSION TESTS

Two-Factor Analysis of Variance (ANOVA) procedures were utilized in this study. ANOVA was first used to show that there is no effect on the listening comprehension tests due to different video contents. Since different video contents might have significant effects on the tests and thus interfere with the main factors (with or without captions) the researcher intended to explore, the first step was crucial. Showing that the video contents had no effect on the tests, the researcher was able to continue exploring further whether 
there were significant effects on the tests due to videos with or without captions.

Based on the visual chart of the experimental treatments shown on page 29, the test results and average scores of the two classes (Class 1 and Class 2 ) are presented. Table II on the following page lists the test results of the students in Class 1, which includes individual test score in each category, namely, vocabulary and inference, and total score on the tests. The test results of thirty subjects were calculated. The average score for Class 1 students viewing videotape "Global Warming" without captions was 13.37, while the average score for students watching the second videotape "Race To Save The Planet" with captions was 15.53. As shown in Table III, the average for class 2 students viewing videotape "Global Warming" with captions was 15.73 , while the average for students watching the second videotape "Race To Save The Planet" without captions was 13.7 .

Table IV shows the results using two-way ANOVA procedures along with F-distribution tests. The first null hypothesis concerning Factor 1 (video contents) was that the video contents would have no effects on the listening comprehension test results, while the alternative hypothesis indicated that there were effects due to different video contents. As shown in Table IV, using 95\% confidence interval we could see that the critical F-ratio value was 0.0039 and the F-ratio value for Factor 1 was 0.000067 . Since the F-ratio set up at the 
TABLE II

TEST RESULTS FOR CLASS 1

'GLOBAL WARMING' WITHOUT CAPTIONS

\begin{tabular}{|c|c|c|c|c|c|c|c|}
\hline No. & VOCABULARY & INFERENCE & TOTAL & NO. & VOCABULARY & INFERENCE & TOTAL \\
\hline 1 & 8 & 9 & 17 & 1 & 10 & 11 & 21 \\
\hline 2 & 3 & 8 & 11 & 2 & 7 & 10 & 17 \\
\hline 3 & 5 & 9 & 14 & 3 & 6 & 9 & 15 \\
\hline 4 & 4 & 7 & 11 & 4 & 10 & 8 & 18 \\
\hline 5 & 4 & 3 & 7 & 5 & 4 & 6 & 10 \\
\hline 6 & 4 & 5 & 9 & 6 & 5 & 11 & 16 \\
\hline 7 & 8 & 8 & 16 & 7 & 6 & 6 & 12 \\
\hline 8 & 4 & 10 & 14 & 8 & 11 & 10 & 21 \\
\hline 9 & 2 & 5 & 7 & 9 & 6 & 10 & 16 \\
\hline 10 & 7 & 9 & 16 & 10 & 4 & 7 & 11 \\
\hline 11 & 3 & 5 & 8 & 11 & 6 & 8 & 14 \\
\hline 12 & 5 & 9 & 14 & 12 & 9 & 12 & 21 \\
\hline 13 & 6 & 13 & 19 & 13 & 1 & 7 & 8 \\
\hline 14 & 2 & 7 & 9 & 14 & 5 & 12 & 17 \\
\hline 15 & 6 & 6 & 12 & 15 & 5 & 9 & 14 \\
\hline 16 & 5 & 4 & 9 & 16 & 4 & 10 & 14 \\
\hline 17 & 7 & 9 & 16 & 17 & 4 & 8 & 12 \\
\hline 18 & 7 & 5 & 12 & 18 & 7 & 10 & 17 \\
\hline 19 & 7 & 9 & 16 & 19 & 3 & 8 & 11 \\
\hline 20 & 7 & 10 & 17 & 20 & 7 & 12 & 19 \\
\hline 21 & 8 & 7 & 15 & 21 & 7 & 11 & 18 \\
\hline 22 & 7 & 6 & 13 & 22 & 6 & 10 & 16 \\
\hline 23 & 9 & 10 & 19 & 23 & 4 & 8 & 12 \\
\hline 24 & 10 & 10 & 20 & 24 & 6 & 9 & 15 \\
\hline 25 & 6 & 4 & 10 & 25 & 7 & 12 & 19 \\
\hline 26 & 7 & 10 & 17 & 26 & 6 & 8 & 14 \\
\hline 27 & 8 & 7 & 15 & 27 & 5 & 14 & 19 \\
\hline 28 & 7 & 6 & 13 & 28 & 8 & 8 & 16 \\
\hline 29 & 4 & 3 & 7 & 29 & 9 & 11 & 20 \\
\hline 30 & 9 & 9 & 18 & 30 & 5 & 8 & 13 \\
\hline
\end{tabular}

'RACE TO SAVE THE PLANET' WITH CAPTIONS 
TABLE III

TEST RESULTS FOR CLASS 2

\begin{tabular}{|c|c|c|c|c|c|c|c|}
\hline \multicolumn{4}{|c|}{$\begin{array}{l}\text { 'RACE TO SAVE THE PLANET' } \\
\text { WITHOUT CAPTIONS }\end{array}$} & \multicolumn{4}{|c|}{$\begin{array}{l}\text { 'GLOBAL WARMING' } \\
\text { WITH CAPTIONS }\end{array}$} \\
\hline NO. & VOCABULARY & INFERENCE & TOTAL & NO. & VOCABULARY & INFERENCE & TOTAL \\
\hline 1 & 4 & 7 & 11 & 1 & 9 & 14 & 23 \\
\hline 2 & 5 & 7 & 12 & 2 & 7 & 8 & 15 \\
\hline 3 & 5 & 9 & 14 & 3 & 6 & 11 & 17 \\
\hline 4 & 7 & 8 & 15 & 4 & 3 & 8 & 11 \\
\hline 5 & 6 & 8 & 14 & 5 & 9 & 10 & 19 \\
\hline 6 & 4 & 5 & 9 & 6 & 7 & 10 & 17 \\
\hline 7 & 5 & 5 & 10 & 7 & 5 & 8 & 13 \\
\hline 8 & 5 & 8 & 13 & 8 & 5 & 10 & 15 \\
\hline 9 & 6 & 9 & 15 & 9 & 3 & 5 & 8 \\
\hline 10 & 8 & 9 & 17 & 10 & 8 & 12 & 20 \\
\hline 11 & 8 & 5 & 13 & 11 & 12 & 17 & 29 \\
\hline 12 & 6 & 6 & 12 & 12 & 8 & 13 & 21 \\
\hline 13 & 6 & 7 & 13 & 13 & 4 & 8 & 12 \\
\hline 14 & 9 & 3 & 12 & 14 & 3 & 8 & 11 \\
\hline 15 & 5 & 6 & 11 & 15 & 6 & 9 & 15 \\
\hline 16 & 3 & 8 & 11 & 16 & 7 & 11 & 18 \\
\hline 17 & 4 & 7 & 11 & 17 & 1 & 4 & 5 \\
\hline 18 & 8 & 12 & 20 & 18 & 5 & 10 & 15 \\
\hline 19 & 6 & 8 & 14 & 19 & 6 & 8 & 14 \\
\hline 20 & 6 & 7 & 13 & 20 & 7 & 10 & 17 \\
\hline 21 & 9 & 10 & 19 & 21 & 3 & 7 & 10 \\
\hline 22 & 8 & 10 & 18 & 22 & 8 & 7 & 15 \\
\hline 23 & 8 & 12 & 20 & 23 & 6 & 9 & 15 \\
\hline 24 & 4 & 8 & 12 & 24 & 2 & 5 & 7 \\
\hline 25 & 6 & 12 & 18 & 25 & 5 & 8 & 13 \\
\hline 26 & 10 & 14 & 24 & 26 & 7 & 12 & 19 \\
\hline 27 & 2 & 3 & 5 & 27 & 8 & 8 & 16 \\
\hline 28 & 4 & 8 & 12 & 28 & 9 & 11 & 20 \\
\hline 29 & 7 & 4 & 11 & 29 & 10 & 14 & 24 \\
\hline 30 & 3 & 9 & 12 & 30 & 6 & 12 & 18 \\
\hline & & AVERAGE $=$ & 13.70 & & & AVERAGE $=$ & 15.73 \\
\hline
\end{tabular}

Note. Scores on the above table are random ordered; i.e., Subject 1 on "Global Warming" is not the same subject as Subject 1 on "Race To Save The Planet." 
0.05 level of confidence was greater than the Factor 1 Fratio, the null hypothesis was not rejected; therefore I concluded that there was no effect due to video contents.

With the same procedure, the second null hypothesis concerning Factor 2 (with or without captions) proposed that videotapes with or without captions would have no effect on the test results, while the alternative hypothesis suggested that there were effects due to captioned or non-captioned videotapes. The F-ratio at $95 \%$ confidence interval was 0.0039 and the F-ratio for Factor 2 was 0.0662 . Since F-ratio was less than the Factor 2 F-ratio, I rejected the null hypothesis and accepted the alternative hypothesis that there were effects due to videotapes with or without captions.

\section{TABLE IV}

TWO-FACTOR ANALYSIS OF VARIANCE

$\begin{array}{lcccc}\text { SOURCE OF VARIATION } & \text { SS } & \text { DF } & \text { MS } & \text { F-RATIO } \\ \begin{array}{l}\text { Factor 1 } \\ \text { (Video Contents) }\end{array} & 0.1333 & 1 & 0.1333 & 0.000067 \\ \begin{array}{l}\text { Factor 2 } \\ \text { (Video W/wO/Captions) }\end{array} & 132.3 & 1 & 132.3 & 0.0662 * \\ * \mathrm{p}<.05 & & & & \end{array}$

T-distribution tests were then used to compare the scores of the two groups viewing captioned and non-captioned videotape. The t-tests also analyzed the vocabulary and the inference test results contained in the test questions respectively. The hypothesis testing for the t-test follows: 
Ho: $\mathrm{X} 1=\mathrm{X} 2$ (no main effects)

$\mathrm{H} 1: \mathrm{X} 2>\mathrm{X} 1$

Reject Ho if the observed statistic $t$ is greater than the critical statistic $t_{i}$ otherwise do not reject Ho

Table $V$ shows a significant difference between the test results of the group viewing videotape "Race To Save The Planet" with captions as compared to the group viewing the same video without captions. The critical value of $t$ set up at the .05 level of significance for one-tailed test in this study was 1.671. The observed critical value for $t$ in Table IV was 2.016. Since the observed $t(2.016)$ was greater than the critical $t(1.671)$, the null hypothesis was rejected and the alternative hypothesis that the group viewing the captioned video scored higher than the group viewing noncaptioned video was accepted. The mean for the group viewing captioned video was 15.53 with a standard deviation of 3.46 , while the mean for the non-captioned video group was 13.7 with a standard deviation of 3.86 .

\section{TABLE V}

RACE TO SAVE THE PLANET: TOTAL SCORES

$\begin{array}{lllll}\text { Treatment } & \text { N } & \text { Mean } & \text { SD } & \text { T } \\ \text { Video/W/C } & 30 & 15.53 & 3.46 & 2.01 * \\ \text { Video/wo/C } & 30 & 13.7 & 3.86 & \\ * \mathrm{p}<.05 & & & & \end{array}$


In Table VI, the mean for the group viewing videotape "Global Warming" with captions was 15.73 with a standard deviation of 5.13, while the mean for the group viewing the same videotape without captions was 13.37 with a standard deviation of 3.88 . Since the observed $t(2.01)$ was greater than the critical $t$ (1.671), I concluded that both groups viewing the videos with captions received significantly higher scores than did the groups viewing the videos without captions.

\section{TABLE VI}

GLOBAL WARMING: TOTAL SCORES

$\begin{array}{lllll}\text { Treatment } & \mathrm{N} & \text { Mean } & \text { SD } & \mathrm{T} \\ \text { Video/W/C } & 30 & 15.73 & 5.13 & 2.016 \text { * } \\ \text { Video/wo/C } & 30 & 13.37 & 3.88 & \\ \text { * } \mathrm{p}<.05 & & & & \end{array}$

In examining the test results the students received in the vocabulary and inference category, the t-test showed two different results: (1) the group viewing captioned video exceeded the group viewing non-captioned video in the inference category, and (2) there was no significant difference between the two groups in the vocabulary category . Table VII shows a mean of 9.43 for the group viewing captioned video "Race To Save The Planet" in the inference category and 7.8 for the group viewing the non-captioned video of the same material. 
TABLE VII

RACE TO SAVE THE PLANET: INFERENCE

Treatment $\mathbf{N}$

Mean

SD

$\mathrm{T}$

Video/W/C

30

9.43

1.96

$2.73 *$

Video/wo/C

30

7.8

2.63

$* \mathrm{p}<.05$

Table VIII reveals that the observed $t(0.368)$ was no greater than the critical value $t(1.671)$. Therefore the null hypothesis that there was no significant difference between the group watching the video with captions and the group without captions in the vocabulary category was accepted.

\section{TABLE VIII}

RACE TO SAVE THE PLANET: VOCABULARY

$\begin{array}{lllll}\text { Treatment } & \text { N } & \text { Mean } & \text { SD } & \text { T } \\ \text { Video/W/C } & 30 & 6.1 & 2.22 & 0.368 \\ \text { Video/Wo/C } & 30 & 5.9 & 2.11 & \\ * \mathrm{p}<.05 & & & & \end{array}$

In Table IX, the results of inference category reported by each group are listed. The number of inference was significantly higher for the captioned video group than for the non-captioned video group. 
TABLE IX

GLOBAL WARMING: INFERENCE

Treatment

N

Mean

SD

$\mathbf{T}$

Video/w/C

30

9.57

2.86

$3.15 *$

Video/wo/C

30

7.4

2.46

$* \mathrm{p}<.05$

Finally, with the same hypothesis testing procedures the t-test did not reveal a significant difference in the vocabulary category in Table $x$.

TABLE X

GLOBAL WARMING: VOCABULARY

Treatment

N

Mean

SD

T

Video/w/C

30

6.17

2.52

0.33

Video/wo/C

30

5.97

2.13

$* \mathrm{p}<.05$

In summary, significant differences were found in the total scores and inference category between the group viewing the videos with captions and the group viewing the videos without captions. However, no significant differences were found between the two groups in the vocabulary category. Bar graphs showing the comparisons of the total scores, vocabulary scores, and inference scores between the captioned video group and non-captioned video group are presented in Figures 1,2 , and 3 respectively. 
Figure 1 shows significant differences between the two groups viewing "Global Warming" with captions and without captions, and also between the groups viewing "Race To save The Planet" with and without captions. The total scores of both captioned video groups represented by the bar graphs shown in the visual chart were above 15 points, while the total scores of both non-captioned video group were below 14 points.

No significant statistical differences were found in Figure 2, where four bar graphs representing vocabulary scores of four experimental treatments did not make much difference. All four bar graphs were just a little bit above or below the 6-point scale.

There were significant differences comparing the inference scores between the groups viewing the two videos with or without captions, indicated by the bar graph shown in Figure 3 .

The interpretation of the results and the implications of the above findings will be discussed with reference to the proposed hypotheses in the next chapter. Support for the hypotheses could help future investigations and applications of captioned video materials in ESL classes. Rejection of the proposed hypotheses might give the researcher a chance to look into those related factors scrupulously. All these applications and investigations might also bring valuable insights into the related field of study. 


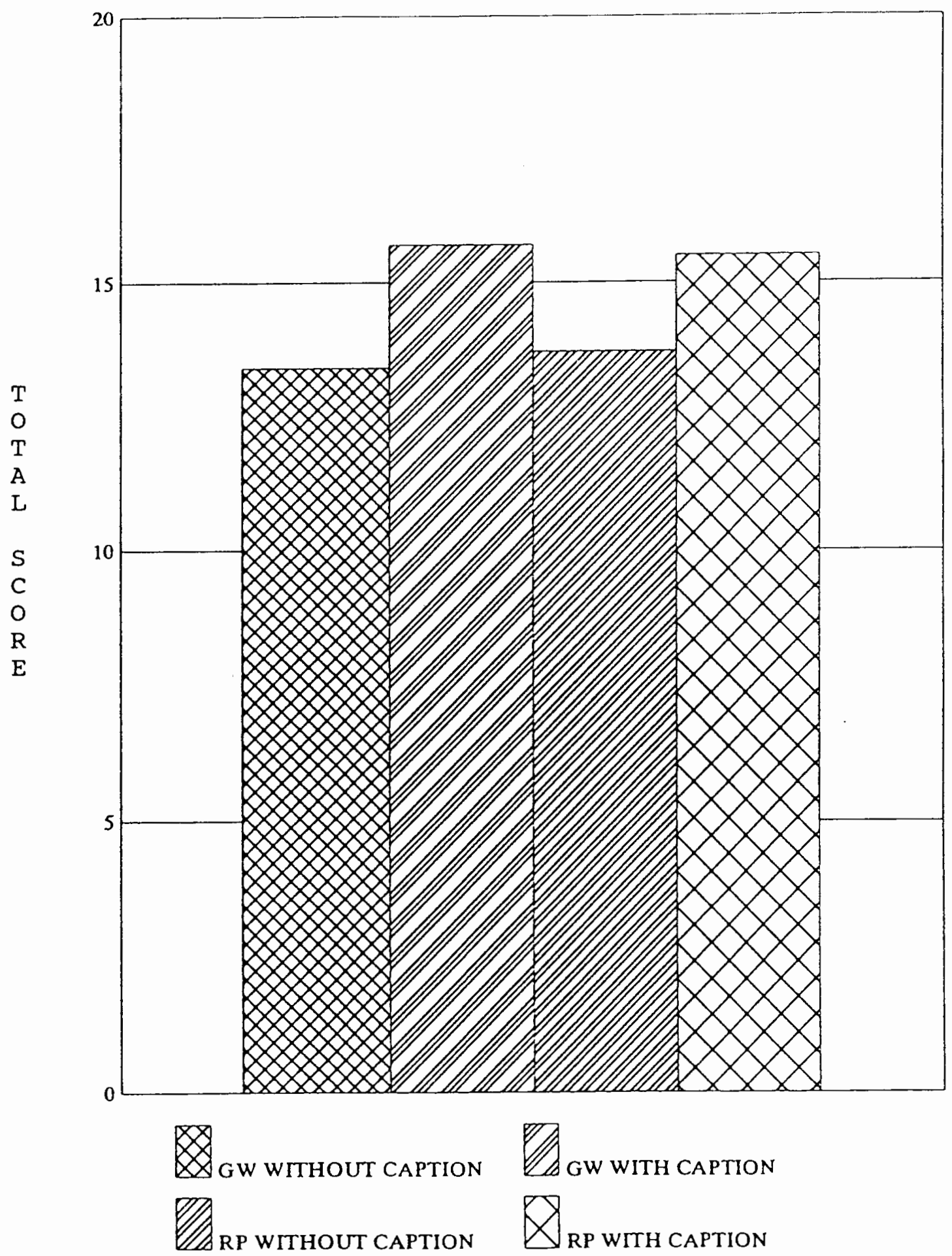

GW: GLOBAL WARMING VIDEO: RP: RACE TO SAVE THE PLANET VIDEO

Fiqure 1. Total score comparisons for videos: with captions vs. without captions. 


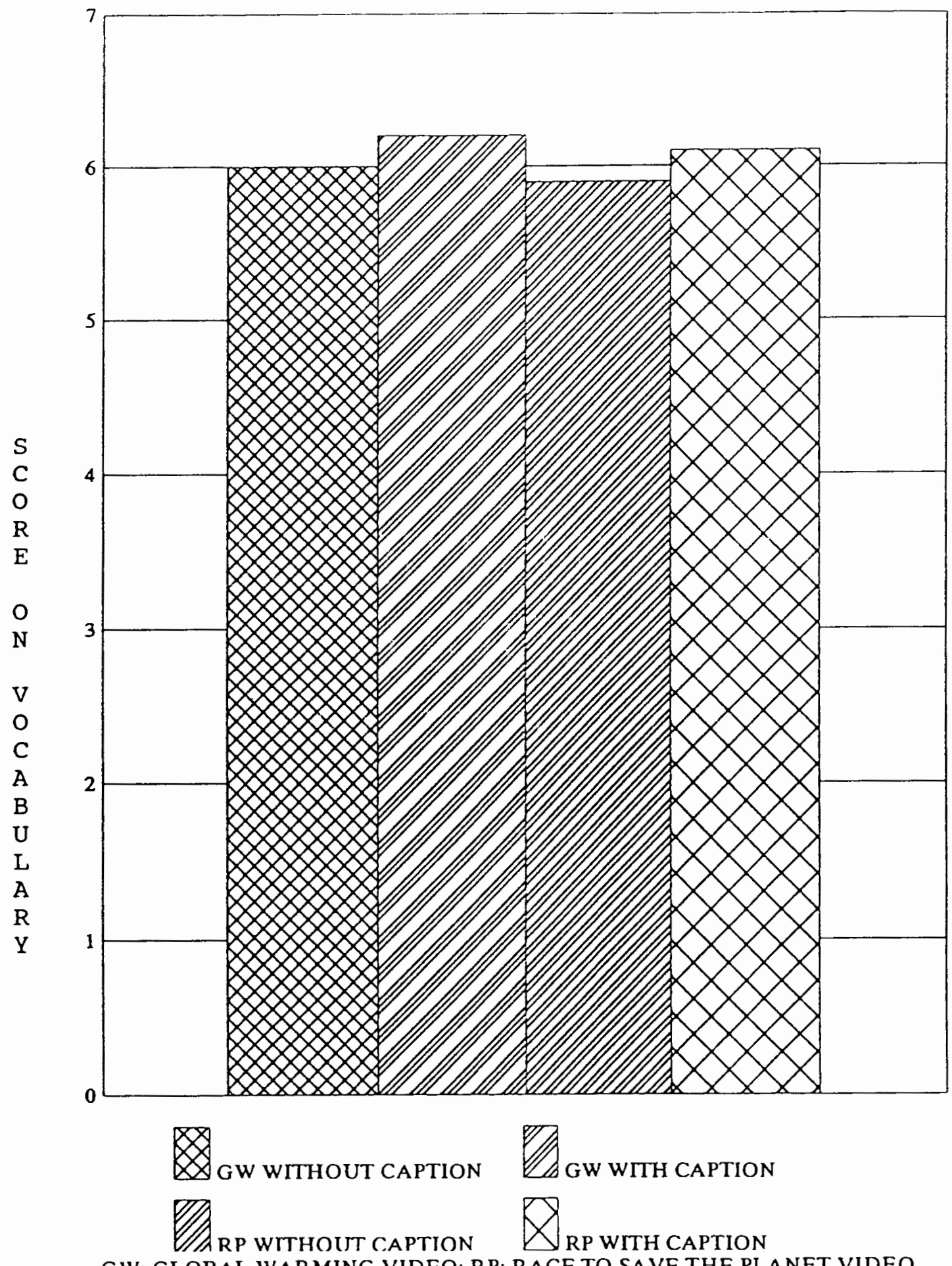

GW: GLOBAL WARMING VIDEO: RP: RACE TO SAVE THE PLANET VIDEO

Fiqure 2. Vocabulary score comparisons for videos: with captions vs. without captions. 


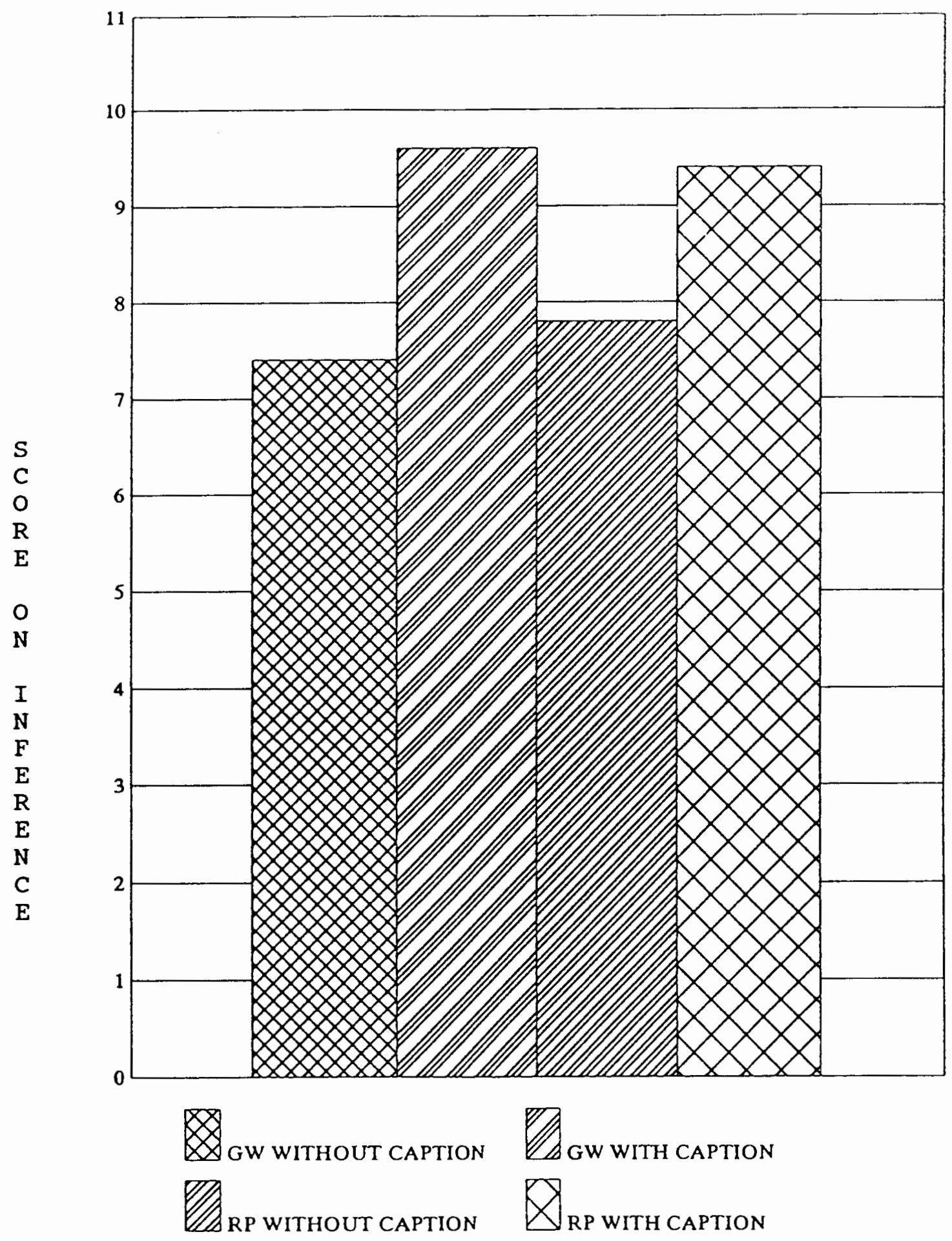

GW: GLOBAL WARMING VIDEO: RP: RACE TO SAVE THE PLANET VIDEO

Figure 3. Inference score comparisons for videos: with captions vs. without captions. 


\section{CHAPTER V}

\section{INTERPRETATION OF TEST RESULTS}

According to the statistical results, those students who received the captioned video treatment outperformed the students receiving the non-captioned video treatment in the inference category and in total scores, while in the vocabulary category there were no statistical differences between the captioned and non-captioned video groups. The statistical differences among the scores of the experimental groups are carefully examined and explained in the following paragraphs.

INTERPRETATION OF THE COMPARISON OF GROUP TEST RESULTS

The results of the comparison between the total scores received by the group viewing captioned videos and the group viewing non-captioned videos supported the first hypothesis that the students watching videotape with captions would score higher than students watching the same video without captions. This finding has been consistent with previous studies comparing captioned video and non-captioned video (see for example: Markham, 1989; Pirolo, 1991). However, the studies were not directly comparable since diverse video materials were employed in the studies. In Pirolo's (1991) study, two 
TV episodes of a dramatic sitcom, "The Cosby Show," were selected for the research, while the videos used by Markham (1989) were two excerpts from the educational program "3-2-1 contact". Since different video contents might bring additional effects on the studies concerning video with or without captions as main factors, further research needs to be explored in order to determine what kinds of captioned video materials best assist in listening comprehension of ESL students.

Comparisons of the two groups scored in the vocabulary and inference category are examined in the following paragraphs.

INTERPRETATION OF THE VOCABULARY RESULTS

The results of the vocabulary category in the tests did not support the second proposed hypothesis that the students watching a captioned videotape would acquire more vocabulary from the captioned video than the students watching the same video without captions. Since the results did not support the hypothesis and were not consistent with the previous studies that students could better recognize the key words or vocabulary from the captioned videos, the possible causes for this outcome need to be examined.

one possible cause might be attributed to the higher level of difficulty concerning the vocabulary contained in the test questions. Although all the questions had been pilot- 
tested and a few difficult words in the vocabulary category had been eliminated, some challenging vocabulary was retained in the tests in order to maintain a normal distribution of difficulty of the test questions. Bothersome words or idioms like "deforestation" and "raise hell" contained in the test questions might have led to unfavorable results.

Another possible explanation might be connected with the testing procedures. The hypothesis that the captioned video group would score higher on the vocabulary than the noncaptioned video group was based on the claims made by some ESL students who possessed telecaption decoders. They thought that viewing captioned TV programs enabled them to follow the messages more easily and learn more vocabulary from the text of captions. If there were any vocabulary items, idioms, or phrases that confused them, they were able to write them down and look them up in the dictionary or consult with their American friends. Since the testing time was limited within fifty minutes per test, students participated in the study were not encouraged to take notes. If the students, regardless of viewing captioned or non-captioned video programs, had been allowed to take notes during each showing and had been granted five to ten minutes to look up items that confused them in the dictionary on their own, the test results might have been different. 
INTERPRETATION OF THE INFERENCE RESULTS

The results concerning the inference category were clearly consistent with the previously discussed findings regarding the value of captioned videos. Students seemed to perform better when the oral messages and visual pictures, together with the showing of the text of captions were presented at the same time during the treatment. Although no statistical differences were found regarding the vocabulary results, the group viewing captioned video clearly outperformed the group viewing the non-captioned video in the inference category. The results might be ascribed to the visibility of the syntactic structures shown in the text of captions which enabled the students to chunk the incoming messages and infer the meanings based on their schema knowledge (Richards, 1983), grammatical competence, and the degree of familiarity with collocations (Brown, 1974) or lexical phrases (Nattinger, 1988).

This research was quasi-experimental because of the inability to randomize the groups. The selected sample populations were focused on the English as a second language or non-native speakers. Thus, results of this study could impact design of ESI courses. The findings of this study did support two of the three hypotheses proposed in Chapter one. The captioned video group scored higher on the total test results and also on the inference results. The only hypothesis rejected was that captioned videos did not have 
effects on the vocabulary results of ESL students participated in this research. 


\section{CHAPTER VI}

\section{CONCLUSIONS AND RECOMMENDATIONS}

This study was conducted to provide some empirical evidence to determine and ascertain the role captioned video plays in the language learning process. The hypotheses posed were based on the researcher's observations of some ESL Chinese students' learning experiences and on newspaper and magazine advertisements advocating the use of captioned materials to improve students' ability to learn English. sixty-four subjects at three colleges participating in the study were evenly divided into two groups and were assigned to either the captioned or non-captioned video treatment. The students would first watch a video either with or without captions and then a second video with or without captions. Multiple-choice tests were administered after each video showing. Three hypotheses were tested based on the results on the listening comprehension tests.

The first hypothesis proposed that the group viewing captioned video would score higher than the group viewing the same video without captions. This hypothesis was supported; the scores of the captioned video group were significantly higher than those of the non-captioned video group. The second hypothesis suggested that the captioned video group 
would recognize more vocabulary than the non-captioned video group. This hypothesis was disconfirmed; in fact, the scores of both groups were not statistically different. The third hypothesis stated that the captioned video group would better understand inference at the word, syntactic, contextual, and thematic level from the text of captions than the group viewing video without captions. This hypothesis was also supported. Again, the scores of the captioned video group were significantly higher than the scores of the non-captioned video group.

\section{CONCLUSIONS FROM STUDY}

The major findings in this research were consistent with the previously discussed studies; only one hypothesis concerning vocabulary in the tests was disconfirmed. The captioned video group's scores were significantly higher in both the inference category and total test results. The use of captioned video materials should certainly be considered as a useful educational tool in the second language classroom. Despite the fact that the group viewing videos without captions did not perform as well as the group viewing captioned videos, it cannot be concluded that captioned video is the best medium for enhancing the listening comprehension skills of ESL students. This study explores the need for further research concerning the use of captioned and noncaptioned video media under various kinds of situations. 
Since the testing methods used in the previous studies and in this study concerning the effects of captioned videos were of the multiple-choice test type, one suggested variable that could be tested could involve a different method of measuring comprehension. An immediate recall protocol test which focuses on the main idea recalled could be employed in future research. Another possible treatment which could be tested would be the employment of different kinds of closed-captioned materials (such as TV soap operas, news, and movies which are originally closed-captioned for the hearing impaired) in the research. Such treatments could determine if the captioned video group would consistently score higher on various closedcaptioned video materials. In this study the taped videos with captions selected from an educational TV program seemed appropriate and effective in increasing listening comprehension of ESL students. A third possible experimental treatment might involve testing after the subjects' exposure to captioned video instruction for a certain period of time. A fourth suggested treatment would be administering pre- and post-test procedures in such experiments. In fact, various affected variables could be tested and help suggest the most suitable and effective methods and procedures that could be employed in the second language teaching.

SUMMARY

The purpose of this study was to confirm or disconfirm 
the assumption that the use of captioned TV programs would enhance the 1istening comprehension of ESL students. The hypotheses of this study were that the subjects viewing captioned videotapes would (1) score higher, (2) acquire more vocabulary, and (3) understand inference at the word, syntactic, contextual, and thematic level from the text of the captions than those viewing the videotapes without captions. The aim of this study was to suggest that the combination of aural messages, visual images, and captions facilitate the listening comprehension ability of ESL students.

There are several limitations to this study. This study was quasi-experimental because the subjects could not be randomly selected although they were randomly assigned to either the control or experimental group. Moreover, since there was a small sample with approximately thirty subjects in each group, statistical differences might be minimal (the vocabulary results turned out to be such a case). Other factors, such as viewer attitude or motivation toward watching captioned videotape, one's previous experience in watching captioned TV programs, and viewer distraction while watching videotape, might affect the study's independent variables. In addition, the viewers might choose to ignore the captions and mainly listen to the aural messages, or to read the captions only instead of listening. These factors were not easily controlled for. However, the researcher tried to control those factors mentioned above by means of careful explanation 
of the purpose for the experiment and instruction of the procedures before each treatment to the subjects in order to minimize the effects that might interfere with the statistical results.

Since the major findings suggested that there were statistical differences indicating the subjects who watched captioned videotapes had better listening comprehension of the contents in two aspects (vocabulary and total test scores) than those watching the videotapes without captions, then the following implications could be made: (1) language educators who make use of videotapes in listening classes should consider employing captioned videotapes in the language laboratory in order to enhance the listening comprehension of ESL students; (2) language educators should familiarize themselves with captioning device and resources for future applications of captioned instruction in ESL classes; language educators might suggest to ESL students that using captioned television at home for regular viewing might assist them to develop their listening comprehension.

In brief, with the extensive availability of modern audio-visual technology and captioned video materials, the benefits of the use of captions at home or in the language laboratory for second language learning and teaching may far exceed the expense of purchasing a telecaption decoder. Moreover, as introduced in the oregonian newspaper (1991) entitled, "Closed Captioning at its Zenith," the first closed 
caption TVs will come into the market this fall. This study suggests that now is the time to give some attention to captioned media which might be a powerful tool in second language teaching in the near future. 


\section{REFERENCES}

Anderson, A. \& Lynch, T. 1988. Listening, Oxford: Oxford University Press.

Berwald, Jean-Pierre. 1979. "Teaching Foreign Language by Means of Subtitled Visuals," Foreign Lanquage Annals, $12,375-378$.

Biggs, Alan. 1990. "Using Movies To Teach Listening Comprehension." Paper presented at the ORTESOL conference, Newberg, OR. April 21, 1990.

Blatt, J. \& Sulzer, J. 1981. "Captioned TV and HearingImpaired Viewers: The Report of a National Survey," American Annals of the Deaf, 126, 1017-1023.

Boyd J. \& Vader, E. 1972. "Captioned TV for the Deaf," American Annals of the Deaf, $117,34-47$.

Braverman, Barbara. 1981. "Television Captioning Strategy: A Systematic Research and Development Approach," American Annals of the Deaf, 126, 1031-i036.

Brown, J. D. 1988. Understanding Research in Second Language Learning. Cambridge, Mass.: Cambridge University Press.

Brown, J. M. \& Palmer, A. 1988. The Listening Approach. White Plains, N.Y.: Longman.

Celona, J. M. 1983. "What does "Wicked Good" Really Mean? Students Talk About Their ESL Problems," MEXTESOL Journal, 7, 42-55.

Chomsky, N. 1965. Aspects of A Theory of Syntax. Cambridge, Mass.: M.I.T. Press.

Cullen, S. 1990. "Making Videotape Lessons Productive." Paper presented at the ORTESOL conference, Newberg, OR. April 21, 1990.

Decker, N. 1980. Readable English for Hearing-Impaired Students: Multilevel Guidelines for Linguistically controlled Reading Materials. WGBH-TV, Boston, Mass.: The Caption Center. (ERIC Reproduction Document No. ED209876) 
Decker, N. \& Montandom, B. 1984. Captioned Media in the Classroom. WGBH-TV, Boston, Mass.: The Caption Center. (ERIC Reproduction Document No. ED 252995)

Durio, H. \& Kildow, C. 1979. Video, Audio and Reading Instructional Presentation of six French Language Scripts: An Evaluation of a Listening comprehension Study. (ERIC Reproduction Document No. ED 188444)

Els, T. V., et al. 1984. Applied Linquistics and the Learning and Teaching of Foreign Language. Baltimore, MD: Edward Arnold.

Friedman, P. 1978. Listening Process: Attention, Understanding, Evaluation. Washington, D.C.: National Education Association.

Goldman, M. \& Goldman, S. 1988. "Reading with closedCaptioned TV," Journal of Reading, 31, 458-461.

Goss, B. 1982. "Listening as Information Processing," Communication ouarterly, 30, 304-307.

Hoffman, D. T. 1986. Soap Opera and Captioning in the EFL Class. Paper presented at the International Conference on Language Teaching and Learning of the Japanese Association of Language Teachers, Hamamatsu, Japan. Nov. 22-23, 1986. (ERIC Reproduction Document No. ED 281392)

Jackson, O. L. 1979. "The Effects of Video vs. Audiotaped Interviews on Listening Comprehension in Third-Quarter, Beginning College French," Dissertation Abstracts International, 40/07A, 3841 .

Krashen, S. 1985. The Input Hypothesis: Issues and Implications, White Plain, N.Y.: Longman.

Liberman, M. 1983. "The Verbal Language of Television," Journal of Reading, 26, 602-609.

Lonergan, J. 1984. Video in Lanquage Teaching, Cambridge, Mass.: Cambridge University Press.

Macwilliam, I. 1986. "Video and language Comprehension," ELT Journal, 40, 131-135.

Markham, P. I. 1989. "The Effects of Captioned Television Videotapes on the Listening Comprehension of Beginning, Intermediate, and Advanced ESL students," Educational Technology, 29, 38-41. 
Morley, J. 1984. Listening and Language Learning in ESL: Developing self-study Activities for Listening Comprehension Practice. (ERIC Reproduction Document No. ED 246697)

Nattinger, J. 1986. "Lexical Phrases, Functions, and Vocabulary Acquisition," The ORTESOL Journal, 7, 1-14.

Thompson, w. 1991. "Closed Captioning at its Zenith," oregonian. August 13, 1991.

Ortmeyer, C. \& Goldstein, B. 1980. Comparing Modes of Instruction Used in Learning to Listen to and Understand English as a Second Language. Research Report, Hong Kong. (ERIC Reproduction Document No. ED 202240)

Parry, T. \& Meredith, R. 1984. "Videotape vs. Audiotape for Listening Comprehension Tests: An Experiment," OMLTA Journal, 47-53. (ERIC Reproduction Document No. ED 254107)

Peck, D. 1986. Insight Into An Audiovisual Approach with Adult ESL students. Paper presented at the Annual Conference of the Pacific and Asian American Educators Association, Honolulu, HI. 1981. (ERIC Reproduction Document No. ED 205651)

Pirolo, N. P. 1991. "Learning English with Closed-Captioned Videos." Paper presented at the NYTESOL conference, New York. March 26, 1991.

Platter, E., et al. 1978. Test Development for Assessing Achievement in Listening and Speaking, Edmont: Alberta Department of Education.

Porter, D. \& Roberts, J. 1987. "Authentic Listening Activities," Methodology in TESOL, Long, M. and Richards, J. (eds.), 177-187. N.Y.: Newbury House.

Powers, D. E. 1985. A Survey of Academic Demands Related to Listening Skills, Test of English as a Foreign Language Research Reports Number 20. Educational Testing Service, Princeton, N.J.. (ERIC Reproduction Document No. ED 304011)

Richards, J. C. 1983. "Listening Comprehension: Approach, Design, Procedure," TESOL Quarterly, 17, 219-240.

Schank, R. \& Abelson, R. 1977. "Scripts, Plans, and Knowledge," Thinking: Reading in Cognitive Science, P. Johnson-Laird \& P. Wason (eds.), 421-432. Cambridge: Cambridge University Press. 
Searls, D., Mead, N. \& Ward, B. 1985. "The Relationship of Students' Reading Skills to TV Watching, Leisure Time, and Homework," Journal of Reading, 29, 158-162.

Shulman, J. 1979. Captioning Reference Manual. Boston: Multilevel Linguistic Captioning Project, The caption Center, WGBH-TV.

Shulman, J. \& Decker, N. 1979. "Multi-level Captioning: A System for Preparing Reading Materials for the Hearing Impaired," American Annals of the Deaf, 124, 559-567.

Svensson, S. E. \& Bogarskola, M. 1985. "Video, Authenticity, and Language for Special Purpose," Foreign Language Annals, 18, 149-152.

Tyson, M. 1989. "The Effect of Media on the Listening Comprehension Scores of Intermediate ESL students." Unpublished thesis, Portland State University, Portland.

Wilson, R. M. \& Koskinen, P. S. 1986. "Closed-Captioned Television," The Exceptional Parent, 16, 46-47.

Wright, S. M. 1971. "Effect of Speaker Visibility on the Listening Comprehension Test Scores of Intermediate Level Students of ESL," Dissertation Abstracts International, $32 / 04 \mathrm{~A}, 2080$. 
APPENDIX A

TRANSCRIPTS OF THE TWO VIDEOTAPES 
RACE TO SAVE THE PLANET

I.

Now on "Race to Save the Planet," stories of people all over the world taking action to save their environment.

People don't feel like -- "the problem is enormous but I can do nothing," "this is something that everybody can do."

From Kenya's farmers fighting deforestation, Russian citizens fighting air pollution, to heads of state and even film stars, people are doing something in the race to save the planet. They've understood that it's now or never!

II.

(Meryl streep)

We've come to the last episode in our series, "Race to save the Planet." We've been all over the world and we've seen an enormous variety of environmental problems. Destruction of the tropical forests, disappearing wildlife, polluted air in our cities, contamination of rivers and oceans, and threats to the global climate. It seems everywhere you look, the environment's under stress, and it really is a race to save the whole sections of this planet. Those tropical forests are disappearing at the rate of an acre a second, and the rate is speeding up. They will be gone in 30 or 40 years, taking with them about a third of world's plants and animals. By the year 2,000 -- that's less than 10 years away -- the earth's climate 
will be warmer than it has been in over 100,000 years. If we don't do something, there will be enormous calamities within a very short time. Now it's very easy to feel helpless in the face of such overwhelming problems. But in this series we've shown that there are ways we can do things differently. We can't live on this planet without destroying it. Of course most of us hate to change the way we do things, but in this final program we explore how much change can come about.

There are people all over the world who have decided that they are going to step in and shake things up. Whether it's international leaders negotiating global agreements, or ordinary people doing extraordinary things in their local community. It does come down to each and every one of us. III.

Changing the world -- we will tell the story of Lu Down, an ex-marine working to close a toxic waste dump in California, and of Larissa Yurtova, who has organized her Moscow neighbors to fight air pollution. We'll meet Wangari Maathai, a dynamic professor who started a nationwide movement to restore Kenya's devastated forests. This Greek businessman devised a way to prevent oil pollution at sea. And because of this diplomat's vision, there's now a treaty protecting the Mediterranean. The environment is on the agenda of prime ministers, and it's on the minds of the film stars. They've all been struck by the urgent need to save the planet -- NOW or NEVER! 
IV.

This is Casmalia, California. The scarcely 200 people who live in this town have the usual things on their minds -- like jobs and kids. But in Casmalia, one concern overshadows them all -- the toxic waste dump next door. It's one of only two facilities in california which accept the state's most toxic industrial waste. Chemicals like benzene, phenol, and cyanide. The dump is located up in the hill about a mile out of town. The state claims that it's not a threat to public health. But residents here are unconvinced.

(Jackson)

"My wife has cancer. She is in bed right now, dying with cancer. I've lost a brother, a sister-in-law, my uncle and aunt, and a beaucoup of friends."

"Two years ago the state Department had told us that we were full of toxic superstition. When people have been seeing that their families and neighbors dying, I see my kid, my youngest Iittle girl has an inch-and-a-half-diameter cyst pulled out of her neck. I've supposed that we are just superstitious. That doesn't cut it, but I am damned angry. That my state Department of Health Service that is supposed to protect me, my family and my neighbor is not doing it, not doing it in the least."

In the early 1980s, the owner of the dump used to spray treated cyanide waste in the air to enhance evaporation. On days when the wind was blowing from the dump, the Casmalia 
school had to be closed repeatedly when the children became ill from the fumes. The spraying has since stopped but the townspeople still worry about the contaminated dust and groundwater. Although it is very difficult to prove this specific illness was caused by exposure to toxic waste, 66 local physicians signed their names to this ad in newspaper. For seven years, area residents have tried to persuade government officials to close the dump down. A leader in the fight has been ex-marine Lou Down, a non-smoker. He has developed emphysema and his wife has cancer.

"It's like going into battle, I guess, and defending your home, your life and your way of life. Do you let people come into your home, beat up your children, murder your family and not saying anything? I can't do that.

After years of failing to get any action the convention way through their county and state government, the people of Casmalia turned to the unconventional. (The environmental group, Greenpeace)

(Angel)

"It's a long fight, it's a difficult fight. There're many obstacles. But the fact is that throughout the country toxic waste dump has been closed, proposed dumps and incinerators have been defeated. It's not because the government has ruled in our favor. That's happened very few circumstances. It's happened where people have educated themselves, organized their friends, neighbors, and their community, and got out and 
raised hell."

"Come to the meeting tomorrow night at $6: 30 . "$

Raising hell is exactly what Casmalia residents have learned they must do. It would be hard to find a more unlikely radical. But even Lou Down has joined Greenpeace as a volunteer.

"When we've cried out for help in the 80's and nobody would listen, Greenpeace came. They helped us, and prior to that I'd have 22 Greenpeace kids sleeping in my house, with long and purple hair and crazy clothes on. I've told them they're nuts. Greenpeace came and they listened and they said, "we want you learn how to do this, to stand up and don't be intimidated." You don't have to be intimidated by elected officials."

Casmalia is no longer intimidated. It was the townspeople who uncovered the fact that the dump was over capacity and informed the federal environmental protection agency. Although a closure order was issued, pending appeal, the dump was allowed to remain in operation.

So today Nick Irmiter and other Casmalia residents are taking matters into their own hands by blockading the dump entrance. (Nick)

"People of Casmalia are shutting down this dump. We've got another person diagnosed with cancer in this down and we're not allowed them coming and killing any more of us." The day's first consignment of waste rolls up to protestors. 
Not far behind, the county sheriff. Their job is to get the growing line of trucks into the dump.

"Everybody has got their own choice made. We have to do what is right, but you want to know the reason that we're doing this is for our town. We're doing this for the people that died that we don't want forgotten, and our kids. You look at our kids here and we can't let it happen any more. It's time to say: enough is enough. So I just want you to know that there're some of us that are willing to take the step over the line."

(Sheriff)

"I command you in the name of the people of the state of California to disperse."

"We are the people."

"If you are not, you should be arrested for violation of 407 , 408, and Penal code section 409."

"I have to advise you you're under arrest."

11 people chose arrest, an act of civil disobedience when they felt legal remedies have been exhausted.

For the people of Casmalia, environmental rights, and the rights of citizenship cannot be separated.

(Lou Down)

"We forget this is our country -- we the people -- that is what our constitution and Bill of Rights says. We the people, we have to take it back and be responsible for what happens." In Washington, Lester Brown of the Worldwatch Institute sees 
such citizen involvement as essential in this critical time. "Given the scale of the problems that we face, it is easy to be discouraged. The encouraging thing is that we know that the kinds of things that need to be done. And we know that as individuals we can all begin to work on it. And no one of us is going to save the world alone. Nor is any country going to save the world alone. We have to begin working together. It's going to take each of us and it's going to take all of us. 


\section{GLOBAL WARMING}

Within 60 years, the greenhouse effect is predicted to warm the earth up to eight degrees. This may bring more droughts and more heat spells, disrupting agriculture worldwide. It may also bring a sea level up to two feet, threatening millions who live near the coast with catastrophic floods. Greenhouse warming is caused by carbon dioxide gas from the burning of coal and oil, by deforestation which releases $\mathrm{CO} 2$ stored in trees, and by the ozone-damaging CFCs. There are also greenhouse gases. Controlling the billion resources of all these gases will require global cooperation on a grand scale. In the Wasatch mountain of Utah in 1989, the delicate process of building consensus on global warming was beginning. Scientists, politicians, and environmentalists gathered at the Sundance Institute for unofficial discussions. A contingent of Soviets inspired the theme: Greenhouse Glasnost. Serving as host was an actor and environmentalist, Robert Redford. "I'd like to propose a toast to our soviet guests and say that our nation has competed for so long and so destructively, and the waste of resources has been both a human and environmental tragedy. And I myself am very honored to be a part of an effort to rechannel imaginations and our talents to a more positive end. So I drink to peace and I drink to healing our planet."

Soviet scientist, Roald Sagdave, set the agenda for 
cooperation.

"In ten years from now, the issue of nuclear survival is going to be completely obsolete. This is ecology, the environment which is to shape our future."

As with ozone, much discussion was devoted to the developing countries with their growing energy needs. Could they avoid the mistake of the West and leapfrog to the energy-efficient technologies?

Noal Browns of the United Nations environmental program:

"These developing countries are saying that we are prepared to cooperate with you, but we've got to redefine the term. We will not dedicate the term if our environment has to be sacrificed. Most of the technology that you have, that are efficient and environmentally benign could be transferred to us at reasonable costs."

In the world where environment links all our destinies, cooperation will be needed between rich and poor, between East and West. "President Reagan once said that if only there would be martians, then the United states and Soviet Union could join together to defend the planet. I think now we have even a more dangerous enemy."

International cooperation will be essential in slowing down greenhouse warming, argued climate scientist Steve Schinder, but individuals can also play an important role. "The first thing we need to do is let people recognize that when they walk out the house they shut off the light switch. 
That's important. Because leaving it on, although it's only a little energy, may not seem like much, but when we multiple that times literally billion people are doing that thousands of times -- that saves the real energy and gives us the right consciousness. Then we need to have efficient automobiles and appliances. That starts to make a really big difference. And ultimately we have to send message to our politicians. We have to tell them we not only expect them to help our economic development, we expect you to find creative solutions so that the economy can develop in an environmentally sustainable way. And if you don't, we are gonna put somebody else in charge." In Washington, President Bush has been slow to act, but he says he's getting the environmental message.

"I think we have taken dramatic strides in environmental awareness, and I readily admit that others have been way out in front of me. That I can tell you this, and I hope I can convince those that are still skeptics that I do care, that it's essential that we all care."

In Moscow, President Mackhail Gorbachev says global cooperation on the environment will be necessary.

"The ecology crisis we are experiencing today is tragic, but convincing proof that the world in which we live is interrelated and independent. We need an appropriate international policy in the field of ecology. Only if we work cooperatively shall we be able to avoid catastrophe. The hour of decision, the hour of historic choice has come." 
It is the hour of decision for the human future. our environment is steadily deteriorating. Destruction of the atmosphere gathers momentum, toxic materials accumulate, and the earth's wild plants and animals disappear. As the century closes, four challenges stand paramount.

First, reduce population growth by improving human welfare and promoting family planning. Our current number of 5 billion are set to double in 60 years, and every environmental problem will get tougher as a result. Population is not just a Third World issue. A child born in America will use 30 times more of the earth's resources than one born in India.

Second, slow greenhouse warming by reducing carbon dioxide emissions. A global treaty will be needed, but meanwhile countries can require fuel-efficient cars, tax carbon dioxide emitters, and develop alternative energy like wind and solar power. Individuals could save energy by insulating their homes, using more efficient lighting, and leaving the car home once in a while. And everybody can plant trees. Third, reduce and recycle waste. Individuals can help by recycling. In theory, 80 percent of materials that gets dumped could be reused. Cooperation can reduce toxic waste at the source by rethinking manufacturing processes, and governments can encourage markets for recycled materials and stiffen penalties for toxic polluters.

Fourth, conserve forests and wild species. The world loses an acre of forest every second, uncounted plants and animals 
every year. Individuals can help by supporting organizations working to preserve wild habitats, and government could provide aids and debt-relief to help developing countries in protecting tropical forests. Meeting these challenges will be the key to sustaining our existence on the planet. (Lester Browns)

"We are at a crossroads. We are going to have tried to get the world back onto a sustainable development path. To do that, we have to make peace with each other. So we can make peace with nature. The two are not unrelated."

Although we are only a single species within nature, we have a unique ability to destroy. Of course, regardless of whether we treat it wisely, the earth will go on. It is we who need the earth. We depend on its bounty to sustain us and our children to come. It's our own future at stake. We're in the race to save ourselves. It's all up to us.

"I don't really know why I care so much. I just have something inside me that tells me that there is a problem and I have got to do something about it. So I'm doing something about it. I think that's what I'll call the god in me, and all of us have a god in us. And that god is the spirit that unites all life, everything that is on this planet. And it might be this voice that is sending ne to something, and I'm sure it's the same voice that is speaking to everybody on this planet. At least everybody who seems to be concerned about the fate of the world, the fate of this planet." 
This has been the final episode in our series. Thanks for joining us. 
APPENDIX B

TEST QUESTIONS 
TEST: "RACE TO SAVE THE PLANET"

Part I: vocabulary

Name : Leve 1

Directions: In questions 1-15, each sentence has an underlined word or phrase. Below each sentence are four other words or phrases, maxked (A), (B), (C), and (D). You are to choose the one word or phrase that best keeps the meaning of the original sentence if it is substituted for the underlined word or phrase.

1. From Kenya's farmer flghting deforestation, to heads of state and even film stars, people are doing something to save the planet.
(A) thawing of frost
(B) clearing of trees
(C) clearing of wildife
(D) cleaning the environment

2. Environmental problems such as contamination of rivers and oceans, and threats to the global climate.
(A) distinction
(C) destruction
(B) corruption
(D) pollution

3. If we don't do something, within a very short $t$ ime.
(A) disasters
(C) worries
(B) distress
(D) accidents

4. An ex-marine, Lou Down, is working to close a toxic waste dump in California.
(A) erosive
(C) poisonous
(B) untainted
(D) purified

5. It's one of only two facilities in california.
(A) plants
(C) offices
(B) buildings
(D) agencies

6. The states claim that it's not a threat to public health, but residents here are unconvinced.
(A) are satisfied with that
(C) don't argue with that
(B) are persuaded of that
(D) don't believe that

7. Two years ago the state Department had told us that we were full of toxic superstition.
(A) myth
(C) supernaturalism
(B) fear
(D) mystery

8. It has happened when people have educated themselves, organized their friends, and got out and raised hell.
(A) cursed someone
(B) created a disturbance
(C) held a meeting
(D) received a severe scolding

9. Nick and other residents are taking matters into their own hands by blockading the dump entrance.
(A) hiding
(C) barricading
(B) defending
(C) locking up 
10. I command you in the name of the people of the state of California to disperse.
(A) assemble
(B) break up
(C) reunite
(D) give up

11. People chose arrest, an act of civil disobedience.
(A) compliance
(B) stubbornness
(C) insubordination
(D) submission

12. Throughout the country toxic waste dumps have been closed, proposed dumps and incinerators have been defeated.
(A) reactor
(C) boiler
(B) heater
(D) cremator

13. We've got another person diagnosed with cancer in this town.
(A) presumed
(C) discovered
(B) investigated
(D) infected

14. We've come to the last episode in our series.
(A) accident
(C) event
(B) state
(D) experience

15. Given the scale of the problems that we face, it is easy to be discouraged.
(A) rate
(C) degree
(B) stage
(D) credit

Part II: Inference

Directions: In questions 1-15, each sentence is taken from the text of the captions in the tape. Read the four possible answers in each question and decide which one best describe the implied meaning of the question 1 isted.

1. "This is something that everybody can do." What does "this" refer to?
(A) To save tropical rain forests
(B) To save the earth
(C) To save endangered animals
(D) To save contaminated rivers and oceans

2. They have understood that it is now or never.

(A) It is urgent that we save the planet $r$ ight now.

(B) It is easy to understand that we can save the planet either now or in the near future.

(c) It is true that to save the planet is out of the question.

(D) It is now or never that we fight against air pollution. 
3. "We've seen an enormous varlety of environmental problems." Which of the following problems was not mentioned in the tape?
(A) destruction of tropical forests
(B) disappearing wildife
(C) contamination of oceans
(D) threat of oil crises

4. "If we don't do something, there will be enormous calamities within a very short time." what kinds of possible calamities will there be?
(A) Contamination of rain forests
(B) Disappearing $x$ ivers and oceans
(C) Possible warmer climate
(D) Recycled materials

5. There are people all over the world who have decided that they are going to step in and shake things up. What does "Step in and shake things up" mean?

(A) Join in the race to change the way we do things and try to save the planet.

(B) Join the Green Berets and fight against terrorism.

(C) Join international conferences and sign a peace treaty.

(D) Join your local community and do some community service.

6. It does come down to each and every one of us.

(A) To save the planet depends upon international leaders.

(B) To save the planet is not quite possible.

(C) To save the planet is everybody's business.

(D) To save the planet is to build a castle in the air.

7. But in Casmalia, one concern overshadows them all --- the toxic dump next door.

(A) Besides jobs and kids, what concerns Casmalia people most is their neighbor's family affairs.

(B) Besides jobs and kids, what concerns Casmalia people most is their own health condition.

(C) Besides jobs and kids, what concerns casmalia people most is the facility which accept toxic industrial waste.

(D) Besides jobs and kjds, what concerns Casmalia people most is how to operate the toxic dump.

8. benzene, phenol, and cyanide are:

(A) poisonous drugs

(B) noxious chemicals

(C) harmless substances

(D) artificial materials 
9. One day when the wind was blowing from the dump, the Casmalia school had to be closed repeatedly when the children became ill from the fumes.

(A) The illness was caused by exposure to the emission of gas fumes from vehicles.

(B) The illness was caused by exposure to the emission of fumes from the nearby factories.

(C) The illness was caused by exposure to the radioactive fallout from the nearby nuclear plant.

(D) The illness was caused by exposure to the spraying of treated cyanide waste from the dump.

10. After years of failing to get any action through their county and state government, the people of casmalia turned to the unconventional.

(A) Casmalia people became angry and went to extremes.

(B) Casmalia people organized themselves and tried to close the dump.

(C) Casmalia people became angry and tried to move away.

(D) Casmalia people organized themselves to fight against criminals.

11. What kind of "Raising hel1" did Casmalia people resort to?

(A) They intimidated the county sheriff.

(B) They arrested the dump owner.

(C) They blockaded the dump entrance.

(D) They confiscated the consignment of toxic waste carried by trucks.

12. It's time to say, "enough is enough." what does this sentence mean?

(A) It's time to shut down the dump because of economic depression.

(B) It's time to close the dump because it is over capacity and threatens the life of Casmalia people.

(C) It's time to shut down the dump because a closure order was issued from federal environmental protection agency.

(D) It's time to close the dump in casmalia because there is one more facility in california which accepts the state's toxic industrial waste, and that is quite enough.

13. There are some of us who are willing to take the step over the line. What does "take the step over the line" refer to later in the episode?

(A) Some Casmalia residents disobeyed and were arrested.

(B) Some Casmalia residents yielded to the police and calmed down.

(C) Some Casmalia residents signed their names to the newspaper advertisement to accuse the threat of toxic waste to public health.

(D) Some Casmalia residents joined the meeting but did not take any action. 
14. 11 people chose arrest, an act of civil disobedience when they felt that "legal remedies had been exhausted."

(A) legal action against the dump is effective.

(B) the sick people in the town are beyond remedy.

(C) there is nothing they can do about it.

(D) the conventional way did not work.

15 In Washington, Lester Brown of the Worldwatch Institute sees such cltizen involvement as essential in this critical time. (A) Lester Brown thinks that citizen involvement is not appropriate.

(B) Lester Brown thinks that Casmalia people overreacted on the toxic dump issue.

(C) Lester Brown thinks that civil disobedience shouldn't be encouraged.

(D) Lester Brown thinks that what Casmalia people did is important and meaningful. 
TEST: "Global WARMING"

Part I: Vocabulary

Name : Leve 1

Directions: In question 1-15, each sentence has an underlined word or phrase. Below each sentence are four other words or phrases, marked (A), (B), (C), and (D). You are to choose one word or phrase that best keeps the meaning of the original sentence if it is substituted for the underined word or phrase.

1. This may bring more droughts and heat spells.
(A) rainy seasons
(B) dry seasons
(C) dry winds
(D) sunny seasons

2. This may bring more droughts, disrupting agriculture worldwide.
(A) obstructing
(C) assisting
(B) destroying
(D) restoring

3. In the wasatch mountain of Utah, the process of building consensus on global warming was beginning.
(A) disapproval
(B) discord
(C) censure
(D) agreement

4. I drink to healing our planet.
(A) protecting
(B) restoring
(C) deteriorating
(D) devouring

5. The issue of nuclear survival will be completely obsolete.
(A) out-of-date
(B) fashionable
(C) urgent
(D) unnecessary

6. Most of the technology that are environmentally benlgn could be transferred to us.
(A) malignant
(B) harmful
(C) available
(D) beneficial

7. And ultimately we have to send messages to our politicians.
(A) early
(B) consecutively
(C) eventually
(D) consequently

8. The economy can develop in an environmentally sustainable way.
(A) suppressive
(B) supplementary
(C) superior
(D) supportable

9. I think we have taken strides in environmental awareness.
(A) degrees
(C) measures
(B) steps
(D) points

10. I hope I can convince those that are stili skeptics that I do care.
(A) persuade
(C) reassure
(B) dissuade
(D) confirm 
11. Our environment is steadily deteriorating.
(A) glving way
(B) growing up
(C) slowing down
(D) wasting away

12. As the century closes, four challenges stand paramount.
(A) parallel
(B) prlmary
(C) obtainable
(D) insignificant

13. Countries can require fuel-efficient cars and tax carbon dioxide emitters.
(A) $\mathrm{f}$ ine
(C) draft
(B) ban
(D) close

14. Governments can encourage markets for recycied materials and stiffen penalties for toxic polluters.
(A) incite
(B) stimulate
(C) stifle
(D) harden

15. We depend on its bounty to sustain us and our children.
(A) $k$ ind help
(B) warm welcome
(C) generous giving
(D) boundless lands

Part I : Inference

Directions: In question 1-15, each sentence is taken from the text of the captions in the tape. Read the four possible answers in each question and decide which one best describes the implied meaning of the question 1 isted.

1. Within 60 years, the greenhouse effect is predicted to warm the earth up to eight degrees. What is a "greenhouse"?

(A) A building made mainly of cement, in which temperature and humidity can be regulated for the preservation of valuable paintings.

(B) A building made mainly of wood, in which temperature and humidity can be regulated for the cultivation of special species of flowers.

(C) A building made mainly of glass, in which temperature and humidity can be regulated for the cultivation of delicate or out-of-season plants.

(D) A building made mainly of bricks, in which temperature and humidity can be regulated for the conservation of precious curios.

2. According to this episode, which of the following threats is not caused by global warming?

(A) A sea level $r$ ise of up to two feet

(B) More rainy seasons with high humidity

(C) Droughts and heat spells

(D) Catastrophic floods 
3. Greenhouse warming is caused by all of the following except

(A) carbon dioxide gas from the burning of oil and coal.

(B) the spraying of treated chemical waste

(C) deforestation which releases carbon dioxide stored in trees.

(D) Ozone-damaging CFCs.

4. I myself am very honored to be a part of an effort to rechannel imaginations and our talents to a more positive end.

(A) to get the U.S. and the U.S.S.R. together to fight with martians.

(B) to get the U.S. and the U.S.S.R. together to discuss dis armament.

(C) to get the U.S. and the U.S.S.R. together to work on greenhouse cultivation.

(D) to get the U.S. and the U.S.S.R. together to build consensus on global warming.

5. Could they avoid the mistakes of the west and leapfrog to energy-efficient technology?

(A) Could the developing countries learn from the past experiences of the West and promote themselves to the level of developed countries?

(B) Could the developing countries learn from the mistakes of the west and employ modern technology in the field of ecology?

(C) Could the developing countries learn from the mistakes of the west and adopt more efficient technology in preventing greenhouse warming?

(D) Could the developing countries neglect the mistakes of the west and follow the steps of the developed countries?

6. President Reagan once said that if only there would be martians, then the U.S. and the U.S.S.R. would join together and defend the planet. I think now we have a more dangerous enemy. What does the "enemy" refer to?
(A) UFOs from outer space
(B) environmental problems
(C) economic recession
(D) air and oil pollution

7. How do individuals play an important role in saving energy?

(A) Leave the light on when one stays up late.

(B) Shut off the light switch when one is out.

(C) Shut off the light switch when going to bed.

(D) Turn on the light at night to keep out burglars.

8. "And if you don't, we will put somebody else in charge." Who is going to be in charge of what?

(A) Politicians should find creative solutions so that the economy could develop in an environmentally sustainable way. (B) Politicians should adopt modern technology so that the economy will be better off worldwide. 
(c) Pollticlans should flad some ways to prevent global crises such as acts of war, starvation, and economic recession.

(D) Politicians should find creative solutions so that all countries could unite for global peace.

9. Our current numbers of 5 billion are set to double in 60 years. Therefore, by the year of 2051, approximately what will be the numbers of population on earth?
(A) 6 billion
(B) 8 billion
(C) 10 billion
(D) 12 billion

10. Population is not just a Third world issue. What does "Third World" refer to?

(A) communist countries of the world

(B) underdeveloped or developing countries of the world

(C) Arabic countries

(D) European countries

11. One of the methods to reduce carbon dioxide emissions is __?

(A) to buy fuel-inefficient cars

(B) to ban all carbon dioxide emitters

(C) to develop alternative energy like solar power

(D) to recycle dumped waste

12. Which of the following can not save energy?
(A) insulate one's house
(B) use more efficient lighting
(C) leave one's car home once in a while
(D) conserve wild species

13. We have to make peace with each other, so that we can make peace with nature. The two are not unrelated.

(A) The two have nothing in common.

(B) The two are interrelated.

(C) The two are no concern of the people.

(D) The two could be linked as having a cause-and-effect relationship.

14. Which of the following is not among the four challenges mentioned?

(A) Reduce population growth

(B) Slow greenhouse warming

(C) Conserve and reproduce waste

(D) Preserve forests and wild species

15. "We are at a crossroads." What does this mean?
(A) We are in a quandary.
(B) We are at the point where we must choose between different courses of action.
(C) We are crossing an intersection without knowing what to do?
(D) We are stuck in a dead-end alley and are trying to find a way out. 
APPENDIX C

SAMPLES 


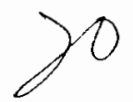

Part I: Vocabulary

TEst: "globat warming"

Name:

Directions: In question 1-15, each sentence has an underlined word or phrase. Below each sentence are four other words or phrases, marked (A), (B), (C), and (D). You are to choose one word or phrase that best keeps the meaning of the original sentence if it is substituted for the underlined word or phrase.

1. This may bring more droughts and heat spells.
(A) ralny seasons
(C) dry winds
(B) tary seasons
(D) sunny seasons

2. This may bring more droughts, disrupting agriculture worldwide.
(A) obstructing
(C) assisting
(B) destroying
(D) restoring

$7^{3}$. In the wasatch mountain of utah, the process of building consensus on global warming was beginning.
(A) disapproval
(C) censure
(B) discord
(D) agreement

4. I grink to healing our planet.
(A) protecting
(C) deteriorating
(B) restor ing
(D) devouring

5. The issue of nuclear survival will be completely obsolete.
(A) out-of-date
(B) fashionable
(C) urgent
(D) unnecessary Most of the technology that are environmentally benign could
be transferred to us.
(A) malignant
(C) avai lable
(B) harmful
(D) beneficlal

7. And ultimately we have to send messages to our politicians.
(A) early
(C) eventually
(B) consecutively
(D) consequently

D 8. The economy can develop in an environmentally sustainable way.
(A) suppress lve
(C) superior
(B) supplementary
(D) supportable

9. I think we have taken styldes in environmental awareness.
(A) degrees
(C) measures
(B) steps
fot points

10. I hope I can convince those that are still skeptics that I docare.

(A) persuade 
11. Our environment is steadily deteriorating.
(A) giving way
(c) slowing down
(B) growing up
(D) wasting away

12. As the century closes, four challenges stand paramount.
(A) parallel
(C) obtainable
(B) primary
(D) Insignificant

13. Countries can require fuel-efflcient cars and tax carbon diexide emitters.
(A) $f$ ine
(C) draft
(B) ban
(D) close

14. Governments can encourage markets for recycled materials and stiffen penalties for toxic polluters.
(A) incite
(B) stimulate
(C) stifle
(D) harden

15. We depend on its bounty to sustain us and our children.
(A) $k$ ind help
(c) generous giving
(B) warm welcome
(D) boundless lands

Part II: Inference

Directions: In question 1-15, each sentence is taken from the text of the captions in the tape. Read the four possible answers in each question and decide which one best describes the implied meaning of the question listed.

1. Within 60 years, the greenhouse effect is predicted to warm the earth up to eight degrees. What is a "qreenhouse"?

(A) A building made mainly of cement, in which temperature and humidity can be regulated for the preservation of valuable paintings.

(B) A buliding made mainly of wood, in which temperature and humidity can be regulated for the cultivation of special spegies of flowers.

(C) A bullding made malnly of glass, in which temperature and humidity can be regulated for the cultivation of delicate or out-of-season plants.

(D) A building made mainly of bricks, in which temperature and humidity can be regulated for the conservation of curios.

2. According to this episode, which of the following threats is not caused by global warming?

(A) A sea level $r$ ise of up to two feet

(B) More rainy seasons with high humidity

(C) Droughts and heat spelis

(D) Catastrophic floods 
3. Greenhouse warming is caused by all of the following except

(A) carbon dioxide gas from the burning of oil and coal.

(B) the spraying of treated chemical waste

(C) deforestation which releases carbon dioxide stored in trees.

(D) ozone-damaging CFCs.

4. I myself am very honored to be a part of an effort to rechannel imaglnations and our talents to a more positive end.

$\overline{(A)}$ to get the U.S. and the U.S.S.R. together to fight with martians.

(B) to get the U.S. and the U.S.S.R. together to discuss d I sarmament.

(C) to get the U.S. and the U.S.S.R. together to work on greenhouse cultivation.

(D) to get the U.S. and the U.S.S.R. together to bulld consensus on global warming.

5. Could they avoid the mistakes of the west and leapfrog to energy-efficient technology?

(A) Could the developing countries learn from the past experlences of the West and promote themselves to the level of developed countries?

(B) Could the developing countries learn from the mistakes of the west and employ modern technology in the fleld of ecelogy?

(C) Could the developing countries learn from the mistakes cof the west and adopt more efficlent technology in preventing greenhouse warmlng?

(D) Could the developing countries neglect the mistakes of the west and follow the steps of the developed countries?

6. President Reagan once sald that if only there would be martians, then the U.S. and the U.S.S.R. would Joln together and defend the planet. I think now we have a more dangerous enemy. What does the "enemy" refer to?

(A) UFOs from outer space (B) environmental problers

(C) economic recession (D) air and oll pollution

7. How do individuals play an important role in saving energy?

(A) Leave the light on when one stays up late.

(B) Shut off the light switch when one is out.

(C) Shut off the light switch when going to bed.

(D) Turn on the 1 ight at night to keep out burglars.

8. "And if you don't, we will put somebody else in charge." who is going to be in charge of what?

(A) Politiclans should find creatlve solutions so that the efonomy could develop in an environmentally sustainable way. (B) Politiclans should adopt modern technology so that the economy will be better off worldwide. 
(C) Politicians should find some ways to prevent global crises such as acts of war, starvation, and economic recession.

(D) Politiclans should find creative solutions so that all countrles could unite for global peace.

9. Our current numbers of 5 billion are set to double in 60 years. Therefore, by the year of 2051, approximately what will be the numbers of population on earth?
(A) 6 blllion
(C) 10 billion
(B) 8 blllion
(D) 12 blllion

10. Population is not just a Third World issue. What does "Third World" refer to?

(B) communist countries of the world

(B) underdeveloped or developing countries of the world

(C) Arabic countries

(D) European countries

11. One of the methods to reduce carbon dloxide emissions is _?

(A) to buy fuel-inefficient cars

(B) to ban all carbon dioxide emitters

(C) to develop alternative energy like solar power

(D) to recycle dumped waste

D 12. Which of the following can not save energy?

(A) insulate one's house

XBD use more efficlent lighting

(C) leave one's car home once in a while

(D) conserve wild specles

$B$ 13. We have to make peace with each other, so that we can make peace with nature. The two are not unrelated.

(A) The two have nothing in common.

(B) The two are interrelated.

(C) The two are no concern of the people.

(D) The two could be linked as having a cause-and-effect relationship.

14. Which of the following is not among the four challenges ment ioned?

(A) Reduce population growth

(B) slow greenhouse warming

(C) Conserve and reproduce waste

(D) Preserve forests and wild species

15. "We are at a crossroads." What does this mean?

(B) We are in a quandary.

(B) we are at the point where we must choose between enferent courses of action.

(C) We are crossing an intersection without knowing what to do?

(D) We are stuck in a dead-end alley and are trying to find a way out. 
TEST: "RACE TO SAVE THE PLANET"

Part I: Vocabulary

Name :

Directions: In questions 1-15, each sentence has an underlined wird or phrase. Below each centence are four other words or phrases, marked (A), (B), (C), and (D).. You are to choose the one word or phrase that best keeps the meaning of the original sentence if it is substituted for the underlined word or phrase.

1. From Kenya's farmer fighting deforestation, to heads of State and even film stars, people are doing something to $B D$ save the planet.
(A) thawing of frost
(C) clearing of wildilfe
(B) clearing of trees
(D) cleaning the environment

2. Environmental problems such as contamination of rivers and oceans, and threats to the global climate.
F (A) distinction
(C) destruction
(B) corruption
(D) pollution

3. If we don't do something,

there will be enormous calamities within a very short time.
(A) disasters
(C) worries
(B) distress
(D) accidents

4. An ex-marine, Lou Down, is working to close a toxic waste dump in California.
(A) erosive
(B) untainted
(C) poisonous
(D) purified

$B^{5}$

It's one of only two facilities in California.
(A) plants
(C) offices
(B) buildings
(D) agencies

6. The states claim that it's not a threat to public health, but residents here are unconvinced.

(A) are satisfied with that (B) are persuaded of that

$\begin{array}{ll}\text { (C) don't argue with that (D) don't believe that } & \end{array}$

2 7. Two years ago the state Department had told us that we were full of toxic superstition.
(A) myth
(B) fear
(C) supernaturalism
(D) mystery

8. It has happened when people have educated themselves. organized their friends, and got out and raised hell.
(A) cursed someone
(B) created a disturbance
(C) held a meeting
(D) received a severe scolding

9. Nick and other residents are taking matters into their own hands by blockading the dump entrance.
(A) hiding
(C) barr lcading
(B) defending
(C) locking up 

B10. I command you in the name of the people of the state of
(A) assemble
(B) break up
(C) reunite
(D) give up

11. People chose arrest, an act of civil disobedience.
(A) compllance
(B) stubbornness
(C) insubordination
(D) submission

12. Throughout the country toxic waste dumps have been closed, proposed dumps and Incinerators have been defeated.
(A) reactor
(C) boiler
(B) heater
(D) cremator

Q

13. We've got another person diagnosed with cancer in this town.
(A) presumed
(C discovered
(B) investigated
(D) Infected

14. We've come to the last episode in our series.
(A) accident
(C) event
(B) state
(D) experience

15. Given the scale of the problems that we face, it is easy to be discouraged.
(A) rate
(C) degree
(B) stage
(D) credit

Part II: Inference

Directions: In questions 1-15, each sentence 19itaken from the text of the captions in the tape. Read the four possible answers in each question and decide which one best describe the implied meaning of the question listed.

f 1. "This is something that everybody can do." What does "this" refer to?
(A) To save tropical rain forests
(B) To save the earth
(C) To save endangered animals
(D) To save contaminated rivers and oceans

$e^{2}$

They have understood that it is now or never.

(A) It is urgent that we save the planet right now.

(B) It is easy to understand that we can save the planet either now or in the near future.

(C) It is true that to save the planet is out of the question.

(D) It is now or never that we fight against air pollution. 
3. "We've seen an enormous variety of environmental problems." Which of the following problems was not mentioned in the tape?
(A) destruction of tropical forests
(B) disappearing wildilfe
(C) contamination of oceans
(D) threat of oil crises

4. "If we don't do something, there will be enormous calamities within a very short time." what kinds of possible calamities will there be?
(A) Contamination of rain forests
(B) Disappearing $r$ ivers and oceans
(C) Possible warmer climate
(D) Recycled materials

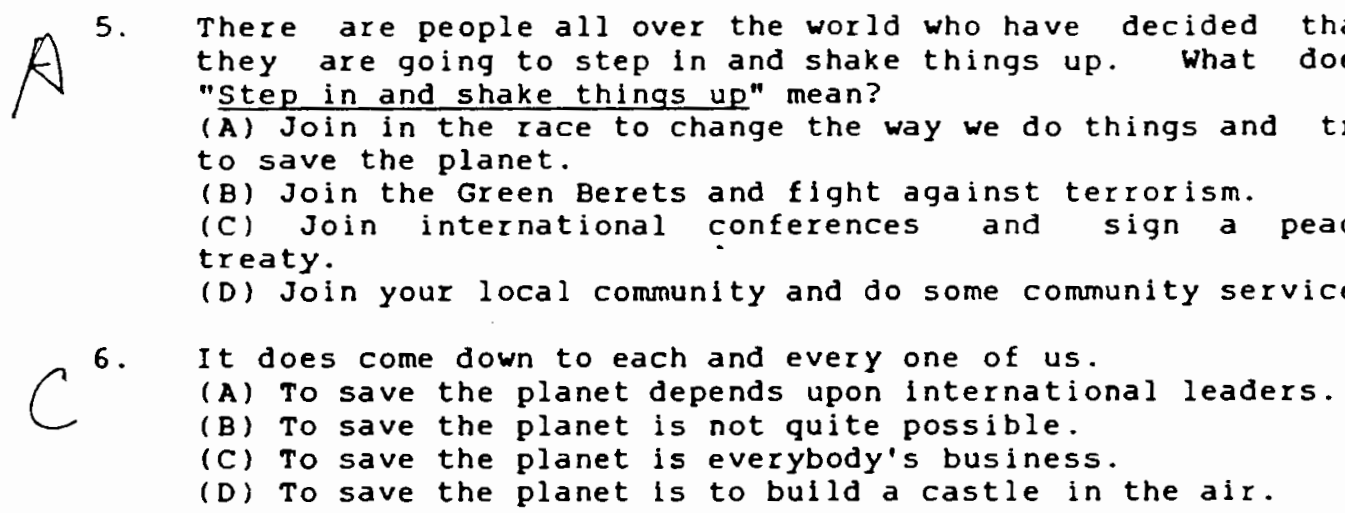

7. But in Casmalia, one concern overshadows them all --- the toxic dump next door.

(A) Besides jobs and kids, what concerns casmalia people most is their neighbor's family affairs.

(B) Besides jobs and kids, what concerns casmalia people most is their own health condition.

(C) Besides jobs and kids, what concerns casmalia people most is the facility which accept toxic industrial waste.

(D) Besides jobs and $k i d s$, what concerns Casmalia people most is how to operate the toxic dump.

7 8 . benzene, phenol, and cyanide are:

(A) poisonous drugs

(B) noxious chemicals

(C) harmless substances

(D) artificial materials 
9. One day when the wind was blowlng from the dump, the $G$ Casmalia school had to be closed repeatedly when the children became ill from the fumes.

(A) The illness was caused by exposure to the emission of gas fumes from vehicles.

(B) The illness was caused by exposure to the emission of fumes from the nearby factories.

(c) The lliness was caused by exposure to the radioactive fallout from the nearby nuclear plant.

(D) The illness was caused by exposure to the spraying of treated cyanide waste from the dump.

10. After years of falling to get any action through their county and state government, the people of Casmalia turned to the unconventional.

(A) Casmalia people became angry and went to extremes.

(B) Casmalia people organized themselves and tried to close the dump.

(C) Casmalia people became angry and tried to move away.

(D) Casmalia people organized themselves to fight against criminals.

$Q^{11}$

What $k$ ind of "Ralsing hell" did Casmalia people resort to?

(A) They intimidated the county sheriff.

(B) They arrested the dump owner.

(C) They blockaded the dump entrance.

(D) They confiscated the consignment of toxic waste carried by trucks.

12. It's time to say, "enough is enough." what does this K sentence mean?

(A) It's time to shut down the dump because of economic depression.

(B) It's time to close the dump because it is over capacity and threatens the life of Casmalia people.

(C) It's time to shut down the dump because a closure order was issued from federal environmental protection agency.

(D) It's time to close the dump in Casmalla because there is one more facility in California which accepts the state's toxic industrial waste, and that is quite enough.

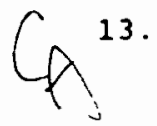

There are some of us who are willing to take the step over the line. What does "take the step over the line" refer to later in the episode?

(A) Some Casmalia residents disobeyed and were arrested.

(B) Some Casmalia residents yielded to the police and calmed down.

(C) Some Casmalia residents signed their names to the newspaper advertisement to accuse the threat of toxic waste to public health.

(D) Some Casmalia residents joined the meeting but did not take any action. 


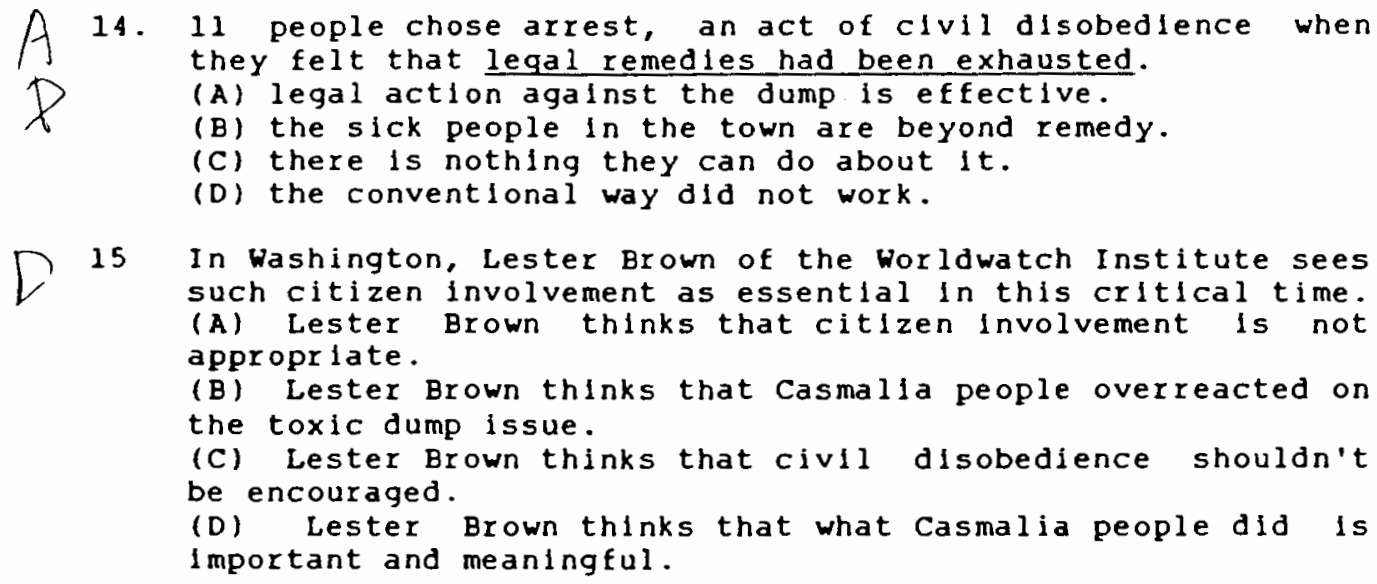

